\title{
23. VOLCANIC ROCKS FROM LEG 67 SITES: MINERALOGY AND GEOCHEMISTRY ${ }^{1}$
}

\author{
R. C. Maury, ${ }^{2}$ H. Bougault, ${ }^{3}$ J. L. Joron, ${ }^{4}$ D. Girard, ${ }^{2}$ M. Treuil, ${ }^{4}$ J. Azéma,${ }^{4}$ J. Aubouin ${ }^{4}$
}

\begin{abstract}
Mineralogical (microprobe) and geochemical (X-ray fluorescence, neutron activation analyses) data are given for 18 samples of volcanic rocks from the Guatemala Trench area (Deep Sea Drilling Project Leg 67). Typical fresh oceanic tholeiites occur in the trench itself (Hole 500) and in its immediate vicinity on the Cocos Plate (Site 495). Several samples (often reworked) of "spilitic" oceanic tholeiites are also described from the Trench: their mineralogy (greenschist facies association-actinolite + plagioclase + chlorite) and geochemistry (alteration, sometimes linked to manganese and zinc mineralization) are shown to result from high-temperature $\left(300^{\circ}-475^{\circ} \mathrm{C}\right)$ hydrothermal seawater-basalt interactions. The samples studied are depleted in light rare-earth elements (LREE), with the exception of the slightly LREEenriched basalts from Hole 500. The occurrence of such different oceanic tholeiites in the same area is problematic.

Volcanic rocks from the Guatemala continental slope (Hole 494A) are described as greenschist facies metabasites (actinolite + epidote + chlorite + plagioclase + calcite + quartz), mineralogically different from the spilites exposed on the Costa Rica coastal range (Nicoya Peninsula). Their primary magmatic affinity is uncertain: clinopyroxene and plagioclase compositions, together with titanium and other hygromagmaphile element contents, support an "active margin" affinity. The LREE-depleted patterns encountered in the present case, however, are not frequently found in orogenic samples but are typical of many oceanic tholeiites.
\end{abstract}

\section{INTRODUCTION}

Eighteen samples of volcanic rocks from Leg 67 sites (Holes 494A, 495, 499B, 499C, 499D, 500, 500B) in the Guatemala Trench have been investigated for major and trace element distributions (by X-ray fluorescence and neutron activation analyses) and compositions of primary minerals (by microprobe). The locations of the sites studied are shown on the schematic cross section of Figure 1 (from Aubouin et al., 1979). The basalts from Site 495 represent the upper part of the oceanic crust of the Cocos Plate, off the Trench. Those from Sites 499 and 500 were recovered in the Trench itself; the samples from Holes 499B and 500 are considered in situ, and represent the first oceanic crust basalts to be sampled in an active trench; lavas from Holes 499C, 499D, and $500 \mathrm{~B}$ were only found as pebbles or reworked materials, and their primary position is unknown. Lastly, volcanic rocks of andesitic (sensu lato) composition were recovered from the bottom of Hole 494A, on the Guatemala continental slope, just above the assumed subduction place; they are overlaid by an Upper Cretaceous to Pleistocene sedimentary sequence.

The study of Leg 67 volcanic rocks thus allows two major problems to be investigated: (1) the behavior of the oceanic crust in a Pacific trench environment; and (2) the magmatic affinity of volcanic rocks drilled in the immediate vicinity of a subduction place.

\footnotetext{
${ }^{1}$ Aubouin, J., von Huene, R., et al., Init. Repts. DSDP, 67: Washington (U.S. Govt. Printing Office),

${ }_{3}^{2}$ Université de Bretagne Occidentale, Avenue Le Gorgeu, 29283 Brest, France.

${ }_{4}^{3}$ Centre Océanologique de Bretagne, Plouzané, 29273 Brest, France.

4 Université Pierre et Marie Curie, Place Jussieu, 75230 Paris, France.
}

\section{LITHOLOGY}

\section{Site 494}

We studied four core-catcher samples from Hole 494A: 29 , CC $(0-4 \mathrm{~cm}), 31, \mathrm{CC}(18-20 \mathrm{~cm}), 33, \mathrm{CC}(30-$ $32 \mathrm{~cm})$, and $35, \mathrm{CC}(8-10 \mathrm{~cm})$. These contain porphyritic volcanic rocks, characterized by abundant, well-preserved clinopyroxene phenocrysts, some of centimeter size. Plagioclase is present as phenocrysts of smaller size and as microphenocrysts. The groundmass contains primary clinopyroxene and plagioclase microlites, but has largely recrystallized as a "spilitic" mineral assemblage: chlorite + albite + epidote + actinolite + quartz. Calcite is sometimes associated with quartz-filled vesicules and veinlets. Summarizing, these samples are typically greenschist facies metabasites, with well-preserved primary clinopyroxenes and plagioclases.

\section{Site 495}

The six samples from Site 495 we studied are: Sample 495-46-1, 138-143 cm, 495-47-1, 3-8 cm, 495-48-1, 19$21 \mathrm{~cm}, 495-48-2,123-126 \mathrm{~cm}, 495-48-4,82-86 \mathrm{~cm}$, and $495-48-4,118-123 \mathrm{~cm}$. All are subaphyric basalts with well-preserved primary texture and mineralogy. Plagioclase is the dominant phenocryst; the groundmass is well-crystallized (plagioclase + clinopyroxene + olivine + magnetite). Olivine is lacking as phenocrysts in the two upper samples (495-46-1 and 495-47-1) and present in the others (495-48-1 to 495-48-4), which presumably belong to another magmatic unit.

\section{Sites 499 and 500}

Hole $499 B$ is represented by two samples: a wellcrystallized subaphyric basalt (499B-10-1, 15-21 cm) with rare plagioclase and clinopyroxene phenocrysts and 


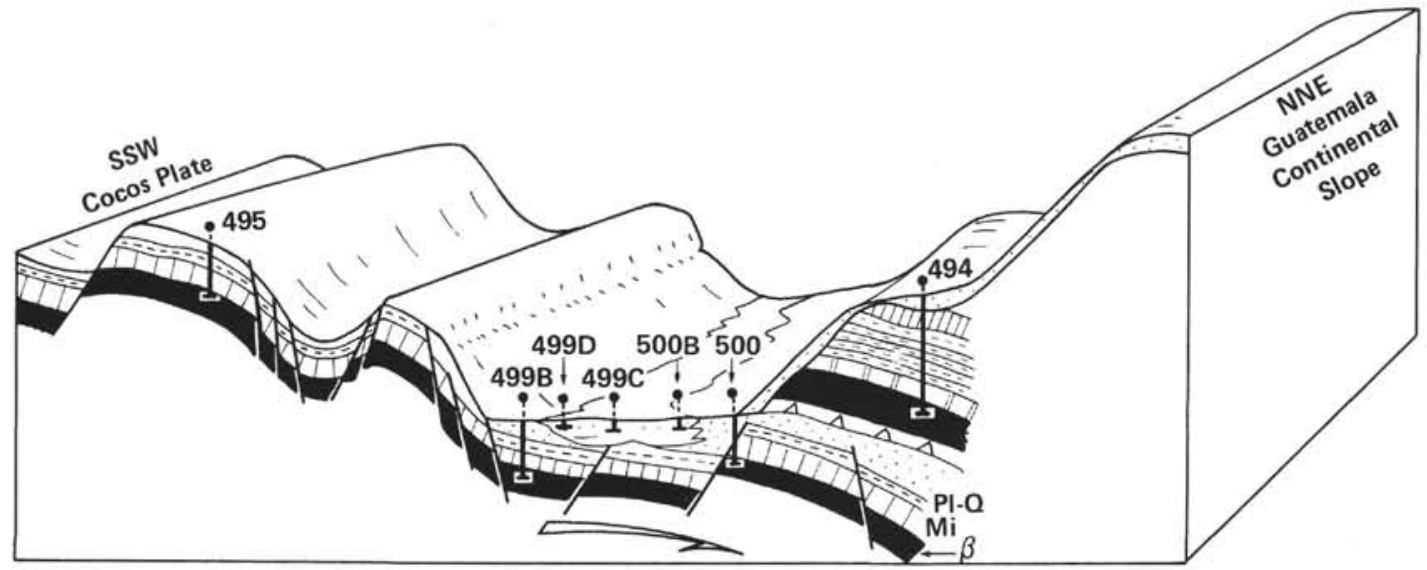

Figure 1. Position of Leg 67 sites (slightly modified from Aubouin et al., 1979). (Pl-Q and Mi = Pliocene-Quaternary and Miocene deposits; $\beta=$ basalts.)

chlorite veinlets in the matrix, and a doleritic coarsegrained basalt (499B-10-140, $46 \mathrm{~cm}$ ), the groundmass of which has suffered a considerable development of actinolite.

Hole 499C. Two coarse-grained basalt samples (499C$1-1,3-4 \mathrm{~cm}$ and $499 \mathrm{C}-1-1,38-43 \mathrm{~cm}$ ) were recovered from this site. They had largely recrystallized to a greenschist facies mineral association: actinolite + chlorite + albite + opaque oxides. The remaining primary minerals are clinopyroxenes and plagioclases (phenocrysts and microlites).

Hole 499D. Sample 499D-1-1, 33-35 cm shows plagioclase and clinopyroxene phenocrysts and microlites in a chlorite- and albite-rich groundmass.

Hole 500. Samples 500-18-1, 52-54 cm and 500-19-1, $24-28 \mathrm{~cm}$ are very well-preserved subaphyric basalts with plagioclase, clinopyroxene, olivine, and spinel in the groundmass and quite rare phenocrysts of olivine, plagioclase, and clinopyroxene. Olivine is altered in Section 500-18-1 and fresh in Section 500-19-1.

Hole 500B. Sample 500B-3-1, 79-88 cm is a coarsegrained basalt very similar to those from Hole 499C. Primary clinopyroxene and plagioclase phenocrysts are dispersed in a groundmass largely recrystallized to chlorite + actinolite + albite, in which pyrite crystals are very abundant.

\section{MAJOR ELEMENT COMPOSITIONS}

$\mathrm{X}$-ray fluorescence analyses are presented in Tables 1 to 3 .

\section{Site 494, Hole 494A (Table 1)}

On the basis of the results at hand, the composition of our samples does not depart very much from the composition of altered oceanic crust basalts. The high values of the loss on ignition are in good agreement with the importance of hydrated phases (chlorite, actinolite) in the metamorphic parageneses of these rocks. $\mathrm{SiO}_{2}$ contents ranging from $48 \%$ to $54.6 \%$ are higher than those of most oceanic tholeiites, and the most silica-rich sample $(494 \mathrm{~A}-31, \mathrm{CC})$ falls in the range of "andesitic" lavas. The interpretation of other major element contents
Table 1. Major element compositions ( $\%$ ), Hole 494A.

\begin{tabular}{lcccc}
\hline & \multicolumn{5}{c}{ Sample (interval in cm) } \\
\cline { 2 - 5 } & $\begin{array}{c}494 \mathrm{~A}-29, \mathrm{CC} \\
(0-4)\end{array}$ & $\begin{array}{c}494 \mathrm{~A}-31, \mathrm{CC} \\
(18-20)\end{array}$ & $\begin{array}{c}494 \mathrm{~A}-33, \mathrm{CC} \\
(30-32)\end{array}$ & $\begin{array}{c}494 \mathrm{~A}-35, \mathrm{CC} \\
(8-10)\end{array}$ \\
\hline $\mathrm{SiO}_{2}$ & 51.88 & 54.62 & 52.94 & 47.99 \\
$\mathrm{TiO}_{2}$ & 0.35 & 0.50 & 0.41 & 0.51 \\
$\mathrm{Al}_{2} \mathrm{O}_{3}$ & 14.60 & 15.43 & 14.61 & 14.78 \\
$\mathrm{Fe}_{2} \mathrm{O}_{3}$ & 8.05 & 9.75 & 7.71 & 8.54 \\
$\mathrm{MnO}$ & 0.14 & 0.27 & 0.12 & 0.16 \\
$\mathrm{MgO}$ & 8.68 & 5.62 & 7.95 & 8.70 \\
$\mathrm{CaO}$ & 8.43 & 5.52 & 3.47 & 7.30 \\
$\mathrm{~K}_{2} \mathrm{O}$ & 0.47 & 0.19 & 0.52 & 0.45 \\
$\mathrm{P}_{2} \mathrm{O}_{5}$ & 0.10 & 0.06 & 0.04 & 0.08 \\
$\mathrm{Loss}$ on ignition & 0.79 & 0.57 & 1.33 & 1.46 \\
$\quad\left(110^{\circ} \mathrm{C}\right)$ & & & & \\
Loss on ignition & 3.32 & 3.27 & 3.96 & 4.99 \\
$\quad\left(1050^{\circ} \mathrm{C}\right)$ & & & & \\
\hline
\end{tabular}

Note: Total iron is expressed as $\mathrm{Fe}_{2} \mathrm{O}_{3}$.

gives some contradictory information concerning the magmatic affinity of Hole 494A samples: $\mathrm{TiO}_{2}$ values of $0.35 \%$ to $0.5 \%$ are compatible with an orogenic magma type, but $\mathrm{Al}_{2} \mathrm{O}_{3}$ values of $14.6 \%$ to $15.4 \%$ remain clearly lower than the mean value of $\mathrm{Al}_{2} \mathrm{O}_{3}$ in andesites; and the $\mathrm{K}_{2} \mathrm{O}$ content of $0.2 \%$ to $0.5 \%$ is close to that of altered oceanic tholeiites and lower than the $\mathrm{K}_{2} \mathrm{O}$ values in andesites.

\section{Site 495 (Table 2)}

All the major element concentrations fall in the range of typical ocean-floor tholeiites. The upper magmatic unit, Sections 495-46-1 and 495-47-1 is $\mathrm{TiO}_{2}$-enriched and $\mathrm{MgO}$ - and $\mathrm{CaO}$-depleted, with respect to the lower unit, Section 495-48-2.

\section{Sites 499 and 500 (Table 3)}

As, at Site 495, all the compositions encountered are typical of oceanic tholeiites. The samples rich in chlorite and actinolite (Section 499C-1-1) show important loss on ignition $(>3.5 \%)$. The small number of samples from Holes 499B and 500 precludes identification of separate magmatic units. 
Table 2. Major element compositions (\%) and C.I.P.W. norms, Site 495.

\begin{tabular}{|c|c|c|c|c|c|c|}
\hline & \multicolumn{6}{|c|}{$\begin{array}{c}\text { Sample } \\
\text { (interval in } \mathrm{cm} \text { ) }\end{array}$} \\
\hline & $\begin{array}{l}495-46-1 \\
138-143\end{array}$ & $\begin{array}{c}495-47-1 \\
3-8\end{array}$ & $\begin{array}{c}495-48-1 \\
19-21\end{array}$ & $\begin{array}{c}495-48-2 \\
123-126\end{array}$ & $\begin{array}{c}495-48-4 \\
82-86\end{array}$ & $\begin{array}{r}495-48-4 \\
118-123\end{array}$ \\
\hline $\mathrm{SiO}_{2}$ & 49.83 & 50.06 & 49.98 . & 50.37 & 50.55 & 50.68 \\
\hline $\mathrm{TiO}_{2}$ & 1.99 & 2.02 & 1.54 & 1.51 & 1.50 & 1.46 \\
\hline $\mathrm{Al}_{2} \mathrm{O}_{3}$ & 15.76 & 16.01 & 16.07 & 15.65 & 15.57 & 14.82 \\
\hline $\mathrm{Fe}_{2} \mathrm{O}_{3}$ & 10.85 & 10.51 & 10.37 & 9.82 & 9.77 & 9.95 \\
\hline $\mathrm{MnO}^{\circ}$ & 0.15 & 0.17 & 0.15 & 0.15 & 0.15 & 0.15 \\
\hline $\mathrm{MgO}$ & 6.05 & 5.93 & 6.56 & 7.37 & 7.40 & 7.03 \\
\hline $\mathrm{CaO}$ & 11.31 & 11.69 & 12.33 & 12.14 & 12.06 & 12.07 \\
\hline $\mathrm{Na}_{2} \mathrm{O}$ & 2.64 & 3.19 & 2.48 & 2.34 & 3.55 & 3.06 \\
\hline $\mathrm{K}_{2} \mathrm{O}$ & 0.39 & 0.39 & 0.28 & 0.27 & 0.09 & 0.28 \\
\hline $\mathrm{P}_{2} \mathrm{O}_{5}$ & 0.25 & 0.31 & 0.16 & 0.20 & 0.16 & 0.17 \\
\hline Total & 99.22 & 100.28 & 99.92 & 99.82 & 100.80 & 99.67 \\
\hline $\begin{array}{l}\text { Loss on ignition } \\
110^{\circ} \mathrm{C}\end{array}$ & 1.67 & 1.62 & 1.24 & 1.15 & 1.11 & 1.38 \\
\hline $\begin{array}{l}\text { Loss on ignition } \\
1050^{\circ} \mathrm{C}\end{array}$ & 1.34 & 1.25 & 1.18 & 0.99 & 0.68 & 1.09 \\
\hline$Q$ & 0.80 & & & 0.54 & & \\
\hline or & 2.34 & 2.32 & 1.67 & 1.61 & 0.53 & 1.67 \\
\hline$a b$ & 22.71 & 27.15 & 21.18 & 19.99 & 29.68 & 26.19 \\
\hline an & 30.52 & 28.39 & 32.20 & 31.73 & 26.30 & 26.19 \\
\hline ne & & & & & 0.19 & \\
\hline (wo & 10.39 & 11.65 & 11.90 & 11.60 & 13.57 & 13.89 \\
\hline di $\{$ en & 5.79 & 6.55 & 6.80 & 7.01 & 8.23 & 8.22 \\
\hline$T_{\text {fs }}$ & 4.19 & 4.63 & 4.58 & 3.96 & 4.60 & 4.98 \\
\hline en & 9.53 & 4.50 & 9.34 & 11.52 & & 5.43 \\
\hline fs & 6.89 & 3.18 & 6.30 & 6.51 & & 3.29 \\
\hline fo & & 2.66 & 0.25 & & 7.15 & 2.85 \\
\hline $\mathrm{fa}$ & & 2.08 & 0.18 & & 4.41 & 1.91 \\
\hline $\mathrm{mt}$ & 2.40 & 2.30 & 2.28 & 2.15 & 2.13 & 2.19 \\
\hline il & 3.84 & 3.86 & 2.95 & 2.90 & 2.85 & 2.81 \\
\hline ap & 0.60 & 0.74 & 0.38 & 0.48 & 0.38 & 0.41 \\
\hline S.I. & 31.85 & 30.98 & 34.89 & 38.87 & 37.03 & 36.11 \\
\hline D.I. & 25.85 & 29.46 & 22.85 & 22.15 & 30.40 & 27.86 \\
\hline
\end{tabular}

Note: Total iron is expressed as $\mathrm{Fe}_{2} \mathrm{O}_{3} ;$ S.I. = Solidification Index; D.I. $=$ Differentiation Index.

\section{MINERALOGY}

All the mineral analyses (1-160) presented in this paper have been obtained with a Camebax automated microprobe (Microsonde Ouest, Brest) under the follow' ing working conditions: $15 \mathrm{KV}, 10-12 \mathrm{nA}$; counting time: $6 \mathrm{~s}$. The value $0.1 \%$ is considered, on the basis of routine analysis, to be the limit of detection, under which the given calculated concentrations are not significant.

\section{Site 494}

Magmatic minerals. The only primary minerals chemically well-preserved in Hole 494A samples are clinopyroxenes (Table 4 ) and plagioclases (Táble 5). The clinopyroxenes plot near the limit of the endiopside and augite fields of the $\mathrm{Ca}-\mathrm{Mg}-(\mathrm{Fe}+\mathrm{Mn})$ diagram (Fig. $2 \mathrm{~A})$. They are characterized by their high $\mathrm{Mg} / \mathrm{Fe}$ ratio, high $\mathrm{SiO}_{2}$ content, low $\mathrm{TiO}_{2}$ and $\mathrm{Al}_{2} \mathrm{O}_{3}$, and relatively high $\mathrm{Cr}_{2} \mathrm{O}_{3}$ (reaching up to $1 \%$ ). Such magnesio-calcic clinopyroxenes of endiopside composition are relatively uncommon in volcanic rocks: they have been found in some ocean-floor basalts (e.g., North Atlantic, Leg 49: Wood et al., 1979), but the compositions encountered are more Ti-rich than those of Hole 494A pyroxenes. Endiopside has also been found in active-margin basalts (Konda, 1970; Le Guen de Kerneizon et al., 1979). Chromiferous diopside, the composition of which is very similar to that encountered in Site 494 rocks, has been shown to crystallize at an early stage of fractionation in

Table 3. Major element compositions ( $\%$ ) and C.I.P.W. norms, Holes 499B, 499C, 499D, 500 , and $500 \mathrm{~B}$.

\begin{tabular}{|c|c|c|c|c|c|c|c|c|}
\hline & \multicolumn{8}{|c|}{$\begin{array}{c}\text { Sample } \\
\text { (interval in } \mathrm{cm} \text { ) }\end{array}$} \\
\hline & $\begin{array}{c}499 \mathrm{~B}-10-1, \\
15-21\end{array}$ & $\begin{array}{c}499 \mathrm{~B}-10-1, \\
40-46\end{array}$ & $\begin{array}{c}499 C-1-1 \\
3-4\end{array}$ & $\begin{array}{c}499 C-1-1 \\
38-43\end{array}$ & $\begin{array}{c}\text { 499D-1-1, } \\
33-35\end{array}$ & $\begin{array}{c}500-18-1, \\
52-54\end{array}$ & $\begin{array}{c}500-19-1, \\
24-28\end{array}$ & $\begin{array}{c}500 \mathrm{~B}-3-1, \\
79-88\end{array}$ \\
\hline $\mathrm{SiO}_{2}$ & 49.96 & 48.82 & 49.89 & 50.03 & 50.49 & 49.80 & 49.14 & 50.42 \\
\hline $\mathrm{TiO}_{2}$ & 0.98 & 0.94 & 1.38 & 1.31 & 0.98 & 1.81 & -1.68 & 1.07 \\
\hline $\mathrm{Al}_{2} \mathrm{O}_{3}$ & 14.73 & 15.39 & 19.77 & 18.76 & 15.42 & 17.77 & 16.28 & 15.16 \\
\hline $\mathrm{Fe}_{2} \mathrm{O}_{3}$ & 8.93 & 9.26 & 7.93 & 9.07 & 9.40 & 8.78 & 9.22 & 9.71 \\
\hline $\mathrm{MnO}$ & 0.14 & 0.16 & 0.31 & 0.39 & 0.16 & 0.12 & 0.14 & 0.18 \\
\hline $\mathrm{MgO}$ & 8.35 & 8.56 & 9.34 & 7.92 & 8.88 & 6.23 & 8.12 & 8.93 \\
\hline $\mathrm{CaO}$ & 12.20 & 12.34 & 6.39 & 8.80 & 12.10 & 11.71 & 11.11 & 12.44 \\
\hline $\mathrm{Na}_{2} \mathrm{O}$ & & & 3.67 & 3.49 & 1.89 & 3.07 & 2.37 & 1.70 \\
\hline $\mathrm{K}_{2} \mathrm{O}$ & 0.10 & 0.09 & 0.19 & 0.16 & 0.04 & 0.43 & 0.65 & 0.05 \\
\hline $\mathrm{P}_{2} \mathrm{O}_{5}$ & 0.09 & 0.11 & 0.14 & 0.09 & 0.08 & 0.31 & 0.29 & 0.09 \\
\hline Total & & & 99.01 & 100.02 & 99.44 & 100.03 & 99.00 & 99.75 \\
\hline $\begin{array}{l}\text { Loss on ignition } \\
110^{\circ} \mathrm{C}\end{array}$ & 0.49 & 0.38 & 1.53 & 1.05 & 0.28 & 2.09 & 1.04 & 0.21 \\
\hline $\begin{array}{l}\text { Loss on ignition } \\
1050^{\circ} \mathrm{C}\end{array}$ & 1.16 & 1.20 & 3.77 & 2.69 & 1.02 & 1.62 & 0.99 & 1.25 \\
\hline$Q$ & & & & & 1.18 & & & 1.60 \\
\hline or & & & 1.14 & 0.95 & 0.24 & 2.56 & 3.91 & 0.30 \\
\hline ab & & & 31.56 & 29.74 & 16.21 & 26.15 & 20.41 & 14.53 \\
\hline an & & & 31.30 & 35.32 & 33.94 & 33.68 & 32.45 & 33.95 \\
\hline co & & & 2.29 & & & & & \\
\hline (wo & & & & 3.37 & 11.01 & 9.51 & 9.07 & 11.62 \\
\hline di $\{$ en & & & & 2.09 & 6.95 & 5.80 & 5.81 & 7.29 \\
\hline fs & & & & 1.08 & 3.37 & 3.17 & 2.67 & 3.61 \\
\hline en & & & 15.05 & 7.69 & 15.46 & 4.68 & 10.18 & 15.18 \\
\hline fs & & & 5.48 & 3.97 & 7.49 & 2.56 & 4.68 & 7.51 \\
\hline fo & & & 6.02 & 7.07 & & 3.60 & 3.22 & \\
\hline $\mathrm{fa}$ & & & 2.42 & 4.02 & & 2.17 & 1.63 & \\
\hline $\mathrm{mt}$ & & & 1.75 & 1.99 & 2.07 & 1.93 & 2.04 & 2.14 \\
\hline il & & & 2.67 & 2.51 & 1.89 & 3.46 & 3.25 & 2.05 \\
\hline ap & & & 0.34 & 0.22 & 0.19 & 0.74 & 0.70 & 0.22 \\
\hline S.1. & & & 45.23 & 39.36 & 45.71 & 35.08 & 41.49 & 45.55 \\
\hline D.I. & & & 32.71 & 30.69 & 17.63 & 28.71 & 24.32 & 16.43 \\
\hline
\end{tabular}

Note: Total iron is expressed as $\mathrm{Fe}_{2} \mathrm{O}_{3} ; \mathrm{S} . \mathrm{I}$. $=$ Solidification Index; D.I. $=$ Diffraction Index. 
Table 4. Clinopyroxenes (in \%) from Hole 494A.

\begin{tabular}{|c|c|c|c|c|c|c|c|c|c|c|c|c|}
\hline \multirow{2}{*}{$\begin{array}{l}\text { Sample 494A-29,CC } \\
(0-4 \mathrm{~cm})\end{array}$} & \multicolumn{12}{|c|}{ Analysis No. } \\
\hline & 1 & 2 & 3 & 4 & 5 & 6 & 7 & 8 & 9 & 10 & 11 & 12 \\
\hline & 50.68 & 52.83 & 52.88 & 51.92 & 53.13 & 54.33 & 52.73 & 52.58 & 52.51 & 53.24 & 52.17 & 53.57 \\
\hline $\mathrm{TiO}_{2}$ & 0.33 & 0.17 & 0.14 & 0.14 & 0.20 & 0.08 & 0.15 & 0.13 & 0.19 & 0.24 & 0.11 & 0.07 \\
\hline $\mathrm{Al}_{2} \mathrm{O}_{3}$ & 6.80 & 2.94 & 3.01 & 3.99 & 2.53 & 1.41 & 3.05 & 3.70 & 2.01 & 1.97 & 3.63 & 3.14 \\
\hline $\mathrm{Cr}_{2} \mathrm{O}_{3}$ & 0.00 & 0.22 & 0.31 & 0.32 & 0.18 & 0.16 & 0.00 & 0.00 & 0.16 & 0.19 & 0.26 & 0.01 \\
\hline $\mathrm{FeO}$ & 6.49 & 5.51 & 5.53 & 4.76 & 5.36 & 5.99 & 6.59 & 5.55 & 6.63 & 6.86 & 5.05 & 4.92 \\
\hline $\mathrm{MnO}$ & 0.20 & 0.14 & 0.16 & 0.23 & 0.09 & 0.20 & 0.19 & 0.11 & 0.11 & 0.13 & 0.00 & 0.14 \\
\hline $\mathrm{MgO}$ & 16.25 & 18.29 & 18.60 & 16.57 & 18.32 & 21.31 & 16.95 & 17.80 & 16.43 & 17.15 & 18.16 & 17.87 \\
\hline $\mathrm{CaO}$ & 18.64 & 19.46 & 18.93 & 21.58 & 19.62 & 16.29 & 19.54 & 20.92 & 20.95 & 20.89 & 19.71 & 20.60 \\
\hline $\mathrm{Na}_{2} \mathrm{O}$ & 0.15 & 0.13 & 0.09 & 0.10 & 0.08 & 0.07 & 0.15 & 0.14 & 0.12 & 0.15 & 0.09 & 0.06 \\
\hline $\mathrm{K}_{2} \mathrm{O}$ & 0.00 & 0.05 & 0.00 & 0.00 & 0.00 & 0.00 & 0.00 & 0.03 & 0.00 & 0.02 & 0.00 & 0.04 \\
\hline Total & 99.54 & 99.74 & 99.65 & 99.61 & 99.51 & 99.84 & 99.35 & 100.96 & 99.11 & 100.84 & 99.18 & 100.42 \\
\hline $\mathrm{Ca}$ & 40.12 & 39.46 & 38.43 & 44.47 & 39.75 & 32.08 & 40.36 & 41.83 & 42.69 & 41.61 & 40.29 & 41.68 \\
\hline $\mathrm{Mg}$ & 48.63 & 51.59 & 52.55 & 47.50 & 51.62 & 58.40 & 48.70 & 49.51 & 46.59 & 47.53 & 51.64 & 50.31 \\
\hline $\mathrm{Fe}+\mathrm{Mn}$ & 11.25 & 8.95 & 9.02 & 8.03 & 8.63 & 9.52 & 10.93 & 8.66 & 10.72 & 10.86 & 8.07 & 8.01 \\
\hline $\begin{array}{l}\text { Sample } 494 \mathrm{~A}-33, \mathrm{CC} \\
(30-32 \mathrm{~cm})\end{array}$ & 13 & 14 & 15 & 16 & 17 & 18 & 19 & 20 & 21 & 22 & 23 & 24 \\
\hline $\mathrm{SiO}_{2}$ & 51.58 & 53.00 & 52.59 & 51.51 & 51.87 & 53.71 & 53.55 & 52.69 & 51.69 & 52.76 & 52.29 & 62.60 \\
\hline $\mathrm{TiO}_{2}^{2}$ & 0.29 & 0.26 & 0.32 & 0.36 & 0.23 & 0.19 & 0.22 & 0.21 & 0.24 & 0.28 & 0.42 & 0.30 \\
\hline $\mathrm{Al}_{2} \mathrm{O}_{3}$ & 3.67 & 3.64 & 3.29 & 4.02 & 3.40 & 1.91 & 1.62 & 2.66 & 3.46 & 3.27 & 4.02 & 2.80 \\
\hline $\mathrm{Cr}_{2} \mathrm{O}_{3}$ & 0.96 & 1.02 & 0.17 & 0.18 & 0.44 & 0.28 & 0.33 & 0.23 & 0.02 & 0.20 & 0.16 & 0.08 \\
\hline $\mathrm{FeÖ}$ & 5.44 & 4.85 & 5.90 & 7.19 & 4.71 & 6.11 & 5.47 & 6.12 & 6.73 & 5.55 & 7.30 & 8.07 \\
\hline $\mathrm{MnO}$ & 0.22 & 0.16 & 0.10 & 0.15 & 0.26 & 0.09 & 0.16 & 0.05 & 0.21 & 0.00 & 0.30 & 0.10 \\
\hline $\mathrm{MgO}$ & 17.88 & 17.30 & 17.18 & 17.08 & 17.00 & 19.11 & 19.57 & 17.79 & 17.20 & 17.55 & 18.97 & 18.35 \\
\hline $\mathrm{CaO}$ & 19.08 & 20.04 & 20.86 & 19.62 & 20.53 & 18.49 & 18.38 & 20.95 & 20.89 & 20.63 & 16.89 & 18.51 \\
\hline $\mathrm{Na}_{2} \mathrm{O}$ & 0.15 & 0.14 & 0.14 & 0.18 & 0.16 & 0.08 & 0.02 & 0.12 & 0.17 & 0.08 & 0.06 & 0.14 \\
\hline $\mathrm{K}_{2} \mathrm{O}$ & 0.00 & 0.00 & 0.01 & 0.00 & 0.00 & 0.03 & 0.02 & 0.00 & 0.00 & 0.00 & 0.00 & 0.00 \\
\hline Total & 99.27 & 100.41 & 100.56 & 100.29 & 98.60 & 100.00 & 99.34 & 100.82 & 100.61 & 100.32 & 100.41 & 100.95 \\
\hline ( $\mathrm{Ca}$ & 39.45 & 41.74 & 42.19 & 39.95 & 42.73 & 37.05 & 36.76 & 41.47 & 41.58 & 41.78 & 34.32 & 33.51 \\
\hline $\mathrm{Mg}$ & 51.41 & 50.10 & 48.33 & 48.38 & 49.20 & 53.25 & 54.45 & 49.00 & 47.65 & 49.44 & 53.61 & 53.50 \\
\hline $\mathrm{Fe}+\mathrm{Mn}$ & 9.14 & 8.16 & 9.48 & 11.67 & 8.07 & 9.70 & 8.79 & 9.53 & 10.78 & 8.78 & 12.07 & 12.99 \\
\hline
\end{tabular}

Note: Analyses numbers 1 to 6 and 13 to 18 are cores of phenocrysts; 7, 8, 19, and 20 are rims of phenocrysts; $9,10,20$ to 24 are microphenocrysts and 11 and 12 microlites.

Table 5. Hole 494A-analyses of primary plagioclases (25-34) and other minerals (in $\%)^{\mathrm{a}}$

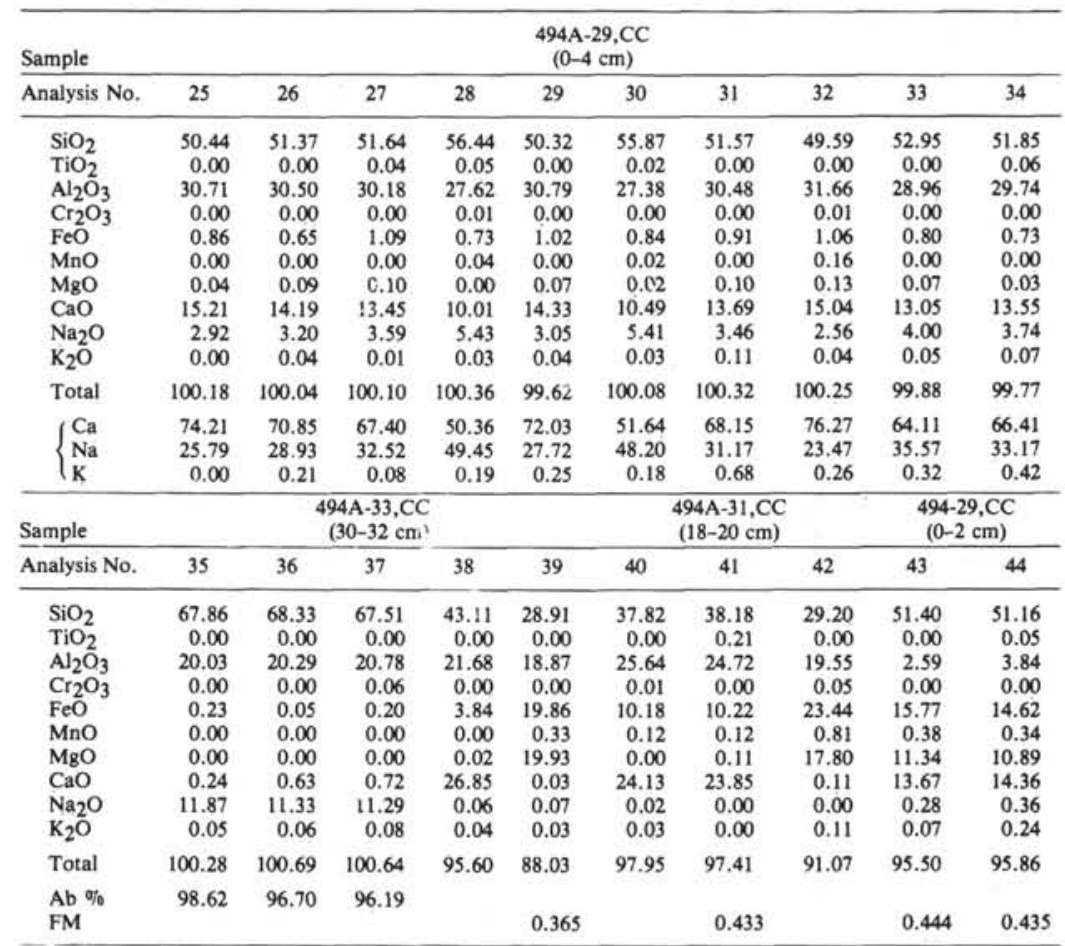

Albite: 35,37 ; epidote: 38,40 ; chlorite: 39,41 ; actinolite: 43,44 . Core of phenocrysts: 25 to $29 ; 35,36$; rims: 30 , 31, 37; groundmass plagioclases: 32 to $34: \mathrm{FM}=(\mathrm{Fe}+\mathrm{Mn}) /(\mathrm{Fe}+\mathrm{Mn}+\mathrm{Mg})$. 

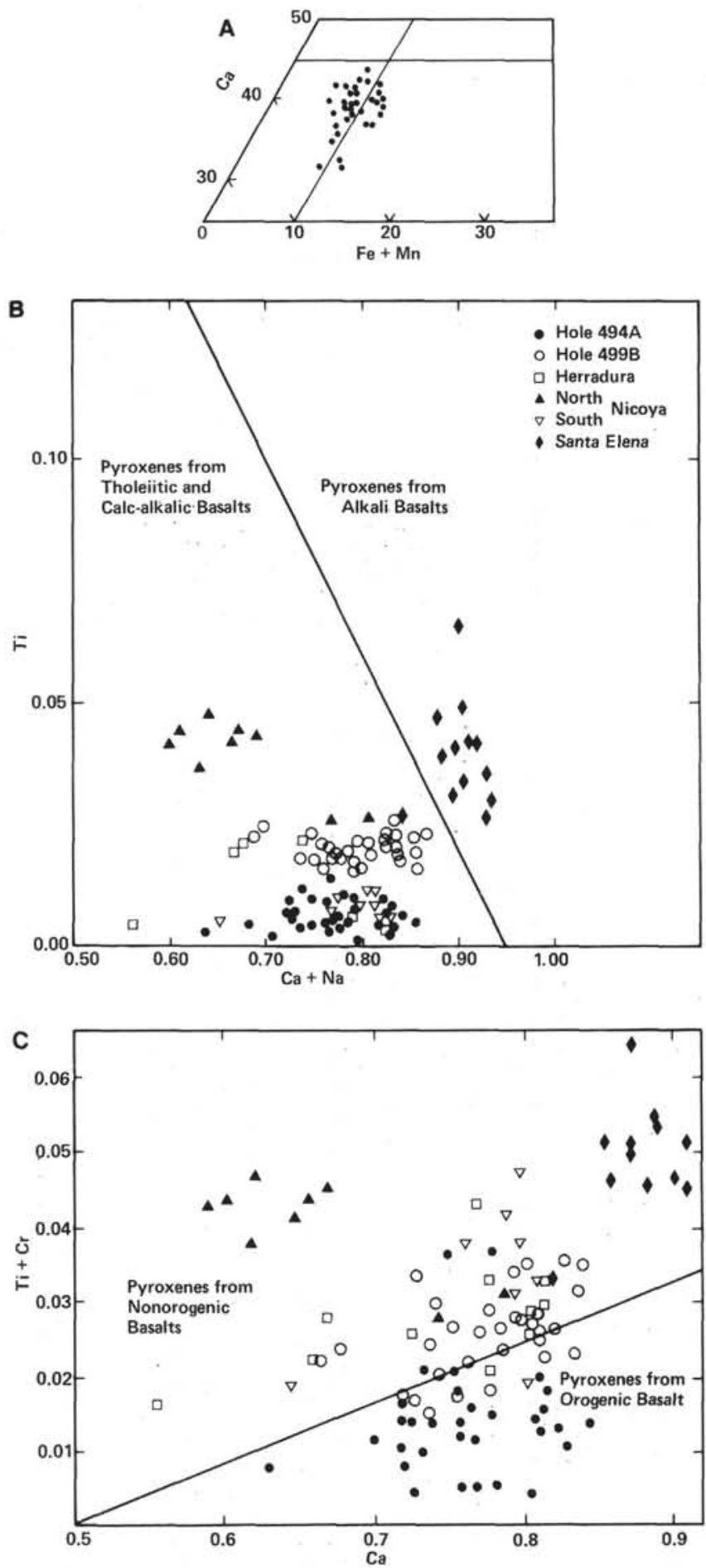

Figure 2. Clinopyroxenes from Hole 494A. A. Position in the Ca-Mg$(\mathrm{Fe}+\mathrm{Mn}$ ) diagram. B and $\mathrm{C}$. Magmatic parentages. (Diagrams after Leterrier et al., personal communication, 1981; cationic proportions in the structural formulae. Pyroxenes from Hole 494A are compared to those from Hole $499 \mathrm{~B}$ and those from the volcanic rocks of Herradura, Nicoya, and Santa Elena formations of the Costa Rica coastal ranges; they are considered tholeiites with ocean-floor affinities.)
New Hebrides island-arc tholeiites (Marcelot, 1980; G. Marcelot, personal communication, 1981).

Plagioclases have undergone variable degrees of albitization: some of them are nearly pure albite (Analyses 35-37, Table 5); others show well-preserved calcic plagioclase compositions (25-34, Table 5), which plot into the bytownite-labradorite field, as do most feldspars from oceanic tholeiites and active-margin basalts. Their zoning is predominantly of normal type. They contain appreciable amounts of iron (total iron as $\mathrm{FeO}$ reaching up to $1 \%$ ), but their magnesium content is low $(\mathrm{MgO}<0.1 \%)$ and the calculated concentrations fall in the range of the analytical precision. They differ in that respect from most plagioclases from ocean-floor tholeiites, including samples from Sites 495, 499, and 500 of Leg 67 and from Leg 66 (Joron et al., 1982), in which $\mathrm{Mg}$ content is usually significantly higher (Hawkins, 1977). The low MgO content would favor an "activemargin" affinity for Hole 494A rocks.

Metamorphic minerals. Although the aim of this work was not the detailed study of late paragenesis, some analyses of epidote, chlorite (pycnochlorite-type), and actinolite are presented in Table 5; the calcic amphibole found in Hole 494A appears to be a true actinolite, following Leake's (1978) classification.

Magmatic affinity of clinopyroxenes from Site 494. Leterrier et al., (personal communication, 1981) have proposed several chemical diagrams useful in differentiating among calcic clinopyroxenes of various magmatic affinities. Hole 494A clinopyroxenes have been plotted in these diagrams (Fig. 2B and 2C), together with pyroxenes from "typical" oceanic crust (Hole 499B) and pyroxenes from basalts of the coastal ranges of Costa Rica (Santa Elena, Nicoya, and Herradura areas). These basalts (samples supplied by J. Tournon) are considered to belong to the oceanic tholeiite magma type (Galli-Olivier, 1979; Azéma and Tournon, this volume), and their structural position is like that of Site 494 rocks (Site 494 report, this volume). Figure 2B shows that Santa Elena pyroxenes plot in the alkali basalt field of a Ti versus $(\mathrm{Ca}+\mathrm{Na})$ diagram, all others being of tholeiitic or calcalkalic affinities. In Figure 2C, most of Hole 494A pyroxenes plot in the orogenic basalt field, those from Hole 499B and Costa Rica coastal ranges plotting into the nonorogenic basalt field (including oceanic tholeiites and alkali basalts). Thus clinopyroxene compositions can be considered to support an "active-margin basalt" parentage for Site 494 volcanic rocks.

\section{Site 495}

On the whole, the mineral composition of Site 495 volcanic rocks is that of typical oceanic tholeiites, showing that oceanic crust can reach the immediate vicinity of an active trench without undergoing any noticeable mineralogical transformation. Olivine and opaque oxides are often altered, as in many ocean-floor samples; clinopyroxenes (Table 6) are relatively iron-rich augites (Fs\%: 17-30), which contain important amounts of $\mathrm{TiO}_{2}$ and $\mathrm{Al}_{2} \mathrm{O}_{3}$; their groundmass pyroxenes (Analyses 49-54, Table 6) are Fe-enriched and Ca-depleted with respect to the microphenocrysts, following a typical tho- 
Table 6. Site 495-pyroxene analyses (in $\%) .^{\mathrm{a}}$

\begin{tabular}{|c|c|c|c|c|c|c|c|c|c|c|}
\hline \multirow{2}{*}{$\frac{\text { Sample }}{\text { Analysis No. }}$} & \multicolumn{6}{|c|}{$495-46-1,138-143 \mathrm{~cm}$} & \multirow{2}{*}{$\frac{495-47-1,3-8}{51}$} & \multicolumn{3}{|c|}{$495-48-4,118-123 \mathrm{~cm}$} \\
\hline & 45 & 46 & 47 & 48 & 49 & 50 & & 52 & 53 & 54 \\
\hline $\mathrm{SiO}_{2}$ & 45.59 & 47.69 & 47.25 & 47.68 & 46.89 & 46.49 & 43.48 & 49.09 & 47.99 & 46.68 \\
\hline $\mathrm{TiO}_{2}$ & 3.56 & 2.54 & 2.80 & 2.55 & 3.28 & 3.17 & 4.43 & 1.38 & 2.35 & 3.09 \\
\hline $\mathrm{Al}_{2} \mathrm{O}_{3}$ & 6.75 & 4.08 & 5.60 & 4.95 & 4.50 & 5.52 & 6.74 & 4.80 & 4.95 & 4.33 \\
\hline $\mathrm{Cr}_{2} \mathrm{O}_{3}$ & 0.15 & 0.04 & 0.34 & 0.21 & 0.00 & 0.27 & 0.21 & 0.30 & 0.09 & 0.09 \\
\hline $\mathrm{FeO}$ & 9.85 & 10.27 & 10.32 & 11.29 & 16.31 & 10.56 & 12.18 & 10.51 & 11.53 & 15.36 \\
\hline $\mathrm{MnO}$ & 0.23 & 0.27 & 0.18 & 0.26 & 0.50 & 0.33 & 0.31 & 0.18 & 0.16 & 0.47 \\
\hline $\mathrm{MgO}$ & 11.79 & 12.65 & 11.82 & 11.82 & 8.36 & 11.18 & 9.66 & 13.76 & 12.04 & 9.66 \\
\hline $\mathrm{CaO}$ & 21.39 & 20.68 & 21.34 & 21.25 & 19.58 & 21.21 & 21.02 & 19.74 & 20.55 & 19.14 \\
\hline $\mathrm{Na}_{2} \mathrm{O}$ & 0.54 & 0.58 & 0.56 & 0.51 & 0.61 & 0.55 & 0.57 & 0.49 & 0.66 & 0.57 \\
\hline $\mathrm{K}_{2} \mathrm{O}$ & 0.00 & 0.00 & 0.01 & 0.02 & 0.03 & 0.00 & 0.00 & 0.00 & 0.03 & 0.00 \\
\hline Total & 99.85 & 98.80 & 100.22 & 100.54 & 100.06 & 99.28 & 98.60 & 100.25 & 100.35 & 99.39 \\
\hline $\mathrm{Ca}$ & 46.84 & 44.48 & 46.41 & 45.49 & 44.17 & 46.85 & 47.55 & 41.80 & 44.27 & 42.59 \\
\hline $\mathrm{Mg}$ & 35.93 & 37.84 & 35.77 & 35.20 & 26.23 & 34.36 & 30.39 & 40.53 & 36.07 & 29.91 \\
\hline $\mathrm{Fe}+\mathrm{Mn}$ & 17.23 & 17.68 & 17.82 & 19.31 & 29.60 & 18.79 & 22.06 & 17.67 & 19.66 & 27.50 \\
\hline
\end{tabular}

${ }^{a}$ Microphenocrysts: 45,47 (cores), 46,48 (corresponding rims); groundmass pyroxenes: 49 to 54 .

leiitic trend of evolution (Fig. 3). The feldspars (Table 7) are normally zoned bytownite phenocrysts and labradorite microlites. Their $\mathrm{K}_{2} \mathrm{O}$ content is very low $(<0.06 \%)$, and their $\mathrm{MgO}$ content appreciable (up to $0.4 \%$ ), as in typical ocean-floor basalts. Again, these feldspars are clearly different from those of Site 494. Albitized plagioclases have never been found.

\section{Sites 499 and 500 (Holes 499B, 499C,} 499D, 500, and 500B)

The mineralogy of samples from these holes is characteristically that of oceanic tholeiites, however, the holes show important differences in their major element compositions. Some samples are very fresh (Hole 500), others show variable extents of development of hydrothermal-metamorphic parageneses characterized by the association actinolite + chlorite + albite + quartz + calcite (499B, 499C, 499D, 500B). Among the latter, only one sample from Hole 499B (499B-10-1, 40-46 cm) has been considered as in situ by the Shipboard team. Lastly, a few samples (499C-1-1, 38-43 cm; 500B-3-1, 79-88 cm) contain manganiferous ilmenite and/or pyrophanite $\left(\mathrm{MnTiO}_{3}\right)$, proving that they have undergone manga- nese mineralization. Pyrite is common in Section 500B3-1.

Olivines have only been preserved in the rocks drilled at Hole 500 (Table 8). They show a progressive iron-enrichment $\left(\mathrm{Fa}_{12}-\mathrm{Fa}_{18}\right)$ from the cores to the rims of phenocrysts and to the groundmass crystals.

Clinopyroxenes show important variations from one hole to another (Table 9). A striking difference appears between Hole 500 pyroxenes (Sample 500-18-1, 52-54 $\mathrm{cm}$ and 500-19-1, 24-28 cm) and those from other holes. Hole 500 pyroxenes (Analyses 97-104, Table 9) are clearly depleted in silica and enriched in $\mathrm{TiO}_{2}, \mathrm{Al}_{2} \mathrm{O}_{3}$, $\mathrm{CaO}$, and $\mathrm{Na}_{2} \mathrm{O}$, compared with the other analyses. Their $\mathrm{TiO}_{2}$ content of $3 \%$ to $5 \%$ is especially high, comparable to that of clinopyroxenes from the titanium-rich alkali basalts of the Polynesian oceanic islands (Tracy and Robinson, 1977; Brousse and Maury, in press); substitution of the $\mathrm{CaTiAl}_{2} \mathrm{O}_{6}$ component plays an essential role in their chemistry. Even if quench trend effects (Smith and Lindsley, 1971) have enhanced their Ti and $\mathrm{Al}^{\mathrm{IV}}$ contents (Mevel and Velde, 1976), all of them being groundmass pyroxenes, it remains undeniable that their chemical composition indicates an "alkalic" tendency

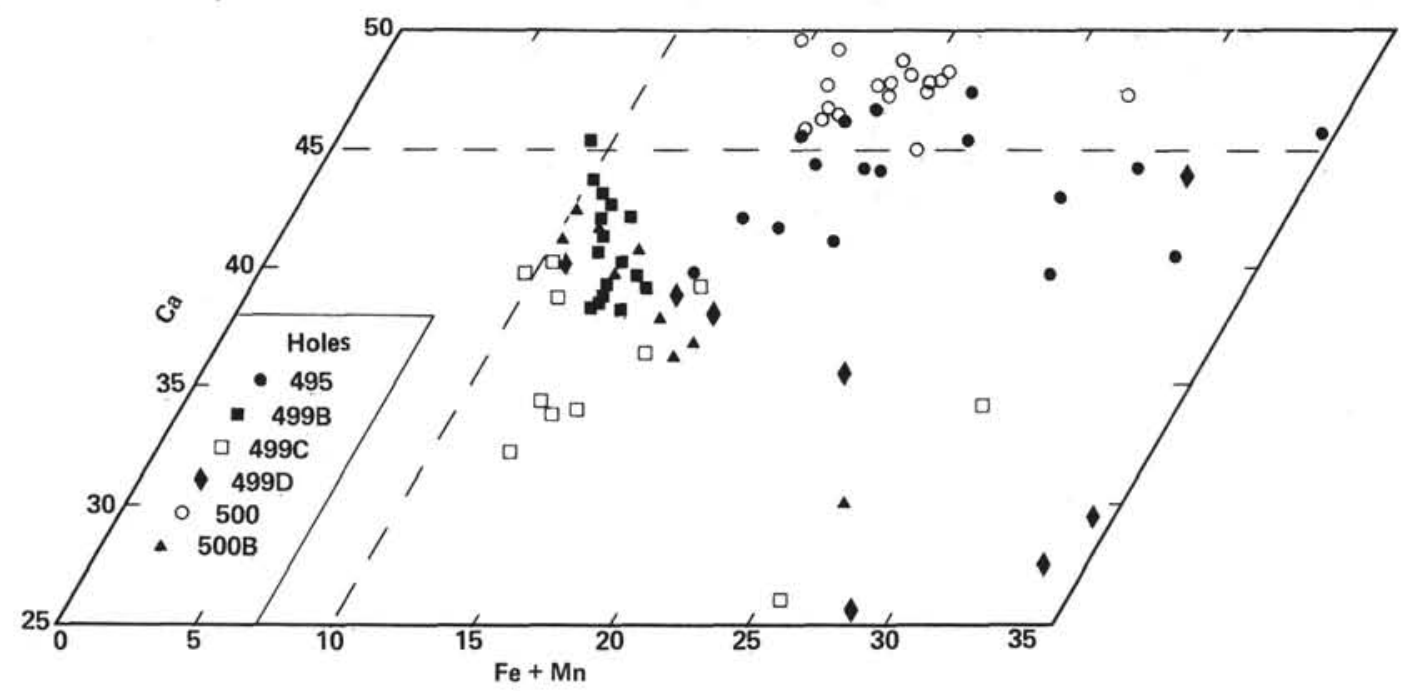

Figure 3. Plot of clinopyroxenes from Sites 495,499 , and 500 in the $\mathrm{Ca}-\mathrm{Mg}-(\mathrm{Fe}+\mathrm{Mn}$ ) diagram. (The calcic ["alkalic"] character of the salites from Site 500 is stressed.) 
Table 7. Site 495: plagioclase analyses (in $\%){ }^{\text {a }}$

\begin{tabular}{|c|c|c|c|c|c|c|c|c|c|c|c|c|c|c|c|c|}
\hline \multirow{2}{*}{$\frac{\text { Sample }}{\text { Analysis No. }}$} & \multicolumn{6}{|c|}{$495-46-1,138-143 \mathrm{~cm}$} & \multicolumn{4}{|c|}{$495-47-1,3-8 \mathrm{~cm}$} & \multicolumn{6}{|c|}{$495-48-4,118-123 \mathrm{~cm}$} \\
\hline & 55 & 56 & 57 & 58 & 59 & 60 & 61 & 62 & 63 & 64 & 65 & 66 & 67 & 68 & 69 & 70 \\
\hline $\mathrm{SiO}_{2}$ & 47.96 & 49.57 & 49.77 & 53.82 & 52.77 & 54.35 & 46.98 & 49.44 & 52.81 & 52.65 & 48.77 & 48.14 & 47.82 & 53.23 & 50.86 & 52.79 \\
\hline $\mathrm{TiO}_{2}$ & 0.00 & 0.00 & 0.02 & 0.09 & 0.08 & 0.14 & 0.00 & 0.08 & 0.00 & 0.09 & 0.00 & 0.00 & 0.00 & 0.03 & 0.05 & 0.00 \\
\hline $\mathrm{Al}_{2} \mathrm{O}_{3}$ & 32.53 & 31.77 & 31.52 & 28.47 & 29.56 & 28.12 & 33.38 & 31.51 & 28.89 & 29.65 & 32.43 & 32.65 & 32.42 & 28.51 & 29.45 & 28.34 \\
\hline $\mathrm{Cr}_{2} \mathrm{O}_{3}$ & 0.00 & 0.08 & 0.00 & 0.00 & 0.13 & 0.00 & 0.00 & 0.08 & 0.00 & 0.00 & 0.08 & 0.00 & 0.00 & 0.00 & 0.00 & 0.09 \\
\hline $\mathrm{FeO}$ & 0.36 & 0.55 & 0.41 & 0.6 & 0.73 & 0.82 & 0.36 & 0.12 & 0.54 & 0.4 & 0.31 & 0.23 & 0.47 & 0.61 & 0.65 & 0.71 \\
\hline $\mathrm{MnO}$ & 0.00 & 0.14 & 0.00 & 0.00 & 0.02 & 0.0 & 0.00 & 0.09 & 0.02 & 0. & 0.14 & 0.01 & 0.00 & 0.10 & 0.00 & 0.05 \\
\hline $\mathrm{MgO}$ & 0.18 & 0.22 & 0.20 & 0.22 & 0.26 & 0.17 & 0.18 & 0.24 & 0.27 & 0.22 & 0.12 & 0.21 & 0.16 & 0.34 & 0.29 & 0.39 \\
\hline $\mathrm{CaO}$ & 16.39 & 15.64 & 15.63 & 12.06 & 12.81 & 11.67 & 17.44 & 15.07 & 12.70 & 13.60 & 16.37 & 16.07 & 17.11 & 12.91 & 14.15 & 13.02 \\
\hline $\mathrm{Na}_{2} \mathrm{O}$ & 2.39 & 2.82 & 2.91 & 4.76 & 4.13 & 5.05 & 1.72 & 2.96 & 4.45 & 4.17 & 2.42 & 2.47 & 2.13 & 4.44 & 3.94 & 4.50 \\
\hline $\mathrm{K}_{2} \mathrm{O}$ & 0.00 & 0.05 & 0.01 & 0.03 & 0.00 & 0.06 & 0.01 & 0.05 & 0.04 & 0.00 & 0.00 & 0.00 & 0.00 & 0.02 & 0.00 & 0.03 \\
\hline Total & 99.81 & 100.84 & 100.47 & 100.09 & 100.49 & 100.38 & 100.07 & 99.64 & 99.72 & 100.86 & 100.64 & 99.78 & 100.11 & 100.19 & 99.39 & 99.92 \\
\hline ( $\mathrm{C}$ & 79.1 & 75.15 & 7 & 58. & & & 0 & 73. & 61 & & 78. & 78.21 & 81.52 & 61.57 & 66.51 & 61.43 \\
\hline ala & 20.85 & 24.54 & 25.19 & 41.62 & 36.84 & 43.78 & 15.16 & 26.16 & 38.73 & 35.68 & 21.08 & 21.79 & 18.42 & 38.30 & 33.49 & 38.40 \\
\hline K & 0.00 & 0.31 & 0.07 & 0.17 & 0.00 & 0.32 & 0.04 & 0.29 & 0.20 & 0.03 & 0.00 & 0.00 & 0.00 & 0.13 & 0.00 & 0.17 \\
\hline
\end{tabular}

${ }^{\text {a }}$ Core-to-rims compositional variations of phenocrysts: 55 to 58 ( $250 \mu \mathrm{m}$ large), 61 to 63 ( $400 \mu \mathrm{m}$ large), 65 to 68 (400 $\mu \mathrm{m}$ large). Groundmass plagioclases: 59,60 , $64,69,70$.

Table 8. Site 500: olivine analyses (in \%). ${ }^{\mathrm{a}}$

\begin{tabular}{|c|c|c|c|c|c|c|c|c|}
\hline \multirow{2}{*}{$\frac{\text { Sample }}{\text { Analysis No. }}$} & \multicolumn{8}{|c|}{$500-19-1,24-28 \mathrm{~cm}$} \\
\hline & 71 & 72 & 73 & 74 & 75 & 76 & 77 & 78 \\
\hline $\mathrm{SiO}_{2}$ & 40.36 & 39.60 & 40.00 & 40.32 & 39.96 & 39.99 & 39.84 & 39.72 \\
\hline $\mathrm{TiO}_{2}$ & 0.02 & 0.04 & 0.00 & 0.00 & 0.02 & 0.00 & 0.04 & 0.00 \\
\hline $\mathrm{Al}_{2} \mathrm{O}_{3}$ & 0.06 & 0.06 & 0.04 & 0.00 & 0.06 & 0.04 & 0.06 & 0.01 \\
\hline $\mathrm{Cr}_{2} \mathrm{O}_{3}$ & 0.00 & 0.06 & 0.00 & 0.06 & 0.10 & 0.02 & 0.04 & 0.05 \\
\hline $\mathrm{FeO}$ & 11.80 & 15.63 & 11.66 & 13.36 & 12.90 & 14.25 & 14.31 & 16.18 \\
\hline $\mathrm{MnO}$ & 0.06 & 0.24 & 0.17 & 0.08 & 0.00 & 0.25 & 0.19 & 0.37 \\
\hline $\mathrm{MgO}$ & 47.82 & 44.23 & 47.53 & 46.82 & 45.77 & 45.86 & 45.58 & 43.55 \\
\hline $\mathrm{CaO}$ & 0.26 & 0.30 & 0.22 & 0.28 & 0.37 & 0.31 & 0.33 & 0.36 \\
\hline $\mathrm{Na}_{2} \mathrm{O}$ & 0.00 & 0.01 & 0.00 & 0.00 & 0.01 & 0.04 & 0.00 & 0.01 \\
\hline $\mathrm{K}_{2} \mathrm{O}$ & 0.00 & 0.00 & 0.00 & 0.00 & 0.00 & 0.00 & 0.00 & 0.05 \\
\hline Total & 100.38 & 100.17 & 99.62 & 100.92 & 99.19 & 100.76 & 100.39 & 100.30 \\
\hline $\mathrm{Fa} \%$ & 12.21 & 16.77 & 12.26 & 13.88 & 13.66 & 15.07 & 15.14 & 17.58 \\
\hline
\end{tabular}

a Cores of phenocrysts (100 m large): 71 and 73 ; corresponding rims: 72 and 74 ; groundmass olivines: 75 to 78 .

of the host magma. This is further shown in Figure 3, where Site 500 pyroxenes plot in the salite field of the $\mathrm{Ca}$ $-\mathrm{Mg}-(\mathrm{Fe}+\mathrm{Mn})$ diagram, all others being augites. The "alkalic" tendency of these pyroxenes, compatible with all their chemical characteristics (Schweitzer et al., 1979), is in excellent agreement with the light REE-enriched pattern of the whole rocks (see the material that follows). Pyroxenes from other sites do not depart from their usual composition in oceanic tholeiites; some samples show restricted compositional variations (e.g., Section 499B-10-1), others are much more scattered in the $\mathrm{Ca}-\mathrm{Mg}-(\mathrm{Fe}+\mathrm{Mn})$ diagram (499C, 499D, 500B).

Feldspars (Table 10) range from primary calcic plagioclase compositions (Sections 500-18-1, 500-19-1), with all the chemical characteristics of oceanic tholeiites $\left(\mathrm{K}_{2} \mathrm{O}\right.$ yery low, $\mathrm{MgO}$ significant), to almost completely albitized feldspars (e.g., Analysis 130, Sample 499C-1-1, 38$43 \mathrm{~cm}$; Analysis 147, Section 500B-3-1). In a given rock (e.g., Sample 499C-1-1, 38-43 cm), progressive compositional variations can be found among the phenocrysts, the normal type zoning of each individual crystal being preserved: $\mathrm{An}_{79}$ to $\mathrm{An}_{68}$ (Analyses 118-121), $\mathrm{An}_{61}$ to $\mathrm{An}_{46}$ (Analyses 122-125), $\mathrm{An}_{44}$ to $\mathrm{An}_{33}$ (Analyses 126129). This pattern of progressive albitization is compatible with the high-temperature water-basalt reaction pro- posed for Hole 499C in the next section on the basis of geochemical considerations.

A magnesiochromite crystal similar to that described in fresh ocean-floor basalts (Sigurdsson and Schilling, 1976; Bougault et al., 1982; Joron et al., 1982) was found in Sample 499B-10-1, 40-46 cm (Analysis 148). (Table 11).

Samples 499C-1-1, 38-43 cm and 500B-3-1, 79-88 cm contain manganiferous oxides $(\mathrm{Mn}, \mathrm{Fe}) \mathrm{TiO}_{3}$ ranging in composition from manganiferous ilmenite to pyrophanite $(\mathrm{Mn}>\mathrm{Fe})$ (Analyses 151, 152, 153, 154, 159). They are generally represented by small opaque grains in the groundmass, but may appear as larger crystals (Analyses 152,153 ) in which $\mathrm{Mn}$ and $\mathrm{Fe}$ concentrations are variable. Pyrophanite occurs mainly in manganese ores, and Mn-enriched magmatic ilmenite is only observed in the most differentiated rocks of volcanic series (Maury et al., 1980). The origin of the manganiferous oxides in Holes $499 \mathrm{C}$ and 500B can thus be ascribed to a postmagmatic stage of mineralization.

Actinolite has been found in basalts of the oceanic crust at the bottom of Hole 499B (Sample 499B-10-1, $40-46 \mathrm{~cm}$ : Analyses 149, 150) and in reworked volcanics from Hole 499C (Analysis 155). Chlorite (pycnochlorite-type) is widespread in samples from Holes 499C, 499D, and 500B (Analyses 156, 157, 158, 160). The clayey brownish minerals developed in these holes were not studied in the course of our research.

\section{TRACE ELEMENTS}

\section{Analytical Method and Results}

Trace element data are presented in Table 12. Data for Hole 487, Leg 66 are presented in the same table because this site is located to the north $\left(15^{\circ} 50^{\prime} \mathrm{N}\right)$ in a position similar to those of Sites 495 or 499 , with respect to the Middle America Trench. The elements are arranged in the order of increasing atomic numbers. The concentrations of $\mathrm{Ti}, \mathrm{Mn}$, and $\mathrm{Fe}$, although not trace elements, have been converted into parts per million $(\mathrm{ppm})$ to present in the same table all the available data 
Table 9. Sites 499 and 500: pyroxene analyses (in \%). ${ }^{\mathrm{a}}$

\begin{tabular}{|c|c|c|c|c|c|c|c|c|c|c|c|}
\hline \multirow{2}{*}{$\frac{\text { Sample }}{\text { Analysis No. }}$} & \multicolumn{8}{|c|}{$499 \mathrm{~B}-10-1,40-46 \mathrm{~cm}$} & \multicolumn{3}{|c|}{$499 \mathrm{C}-1-1,38-43 \mathrm{~cm}$} \\
\hline & 79 & 80 & 81 & 82 & 83 & 84 & 85 & 86 & 87 & 88 & 89 \\
\hline $\mathrm{SiO}_{2}$ & 51.11 & 52.66 & 51.75 & 51.96 & 51.64 & 52.02 & 51.76 & 51.79 & 51.63 & 52.26 & 51.85 \\
\hline $\mathrm{TiO}_{2}$ & 0.78 & 0.51 & 0.56 & 0.57 & 0.76 & 0.62 & 0.59 & 0.76 & 0.63 & 0.55 & 0.65 \\
\hline $\mathrm{Al}_{2} \mathrm{O}_{3}$ & 4.91 & 2.25 & 3.59 & 2.35 & 3.99 & 3.19 & 3.02 & 2.89 & 3.42 & 3.09 & 2.61 \\
\hline $\mathrm{Cr}_{2} \mathrm{O}_{3}$ & 0.44 & 0.00 & 0.33 & 0.00 & 0.41 & 0.30 & 0.00 & 0.10 & 0.46 & 0.19 & 0.07 \\
\hline $\mathrm{FeO}$ & 5.56 & 8.48 & 6.92 & 9.59 & 6.06 & 7.14 & 8.52 & 7.50 & 5.94 & 6.47 & 8.87 \\
\hline $\mathrm{MnO}$ & 0.00 & 0.26 & 0.18 & 0.29 & 0.09 & 0.13 & 0.17 & 0.26 & 0.21 & 0.12 & 0.23 \\
\hline $\mathrm{MgO}$ & 15.48 & 16.83 & 16.74 & 16.53 & 16.00 & 16.39 & 16.42 & 15.85 & 17.79 & 17.40 & 16.82 \\
\hline $\mathrm{CaO}$ & 21.52 & 18.72 & 19.73 & 18.43 & 21.31 & 20.07 & 19.21 & 20.67 & 19.61 & 19.68 & 18.90 \\
\hline $\mathrm{Na}_{2} \mathrm{O}$ & 0.30 & 0.30 & 0.25 & 0.28 & 0.30 & 0.28 & 0.26 & 0.26 & 0.26 & 0.24 & 0.25 \\
\hline $\mathrm{K}_{2} \mathrm{O}$ & 0.02 & 0.00 & 0.00 & 0.00 & 0.00 & 0.00 & 0.07 & 0.00 & 0.03 & 0.00 & 0.00 \\
\hline Total & 100.12 & 100.01 & 100.05 & 100.00 & 100.56 & 100.14 & 100.02 & 100.08 & 99.98 & 100.00 & 100.25 \\
\hline $\mathrm{Ca}$ & 45.40 & 38.23 & 40.63 & 37.51 & 44.06 & 41.35 & 39.33 & 42.37 & 39.88 & 40.12 & 38.26 \\
\hline $\mathrm{Mg}$ & .44 & .83 & .95 & 6.79 & 46.01 & 46.97 & 46.78 & 45.21 & 50.35 & 49.37 & 47.36 \\
\hline $\mathrm{Fe}+\mathrm{Mn}$ & 9.16 & 13.94 & 11.42 & 15.70 & 9.93 & 11.68 & 13.89 & 12.41 & 9.77 & 10.50 & 14.38 \\
\hline Sample & \multicolumn{3}{|c|}{$499 \mathrm{C}-1-1,38-43 \mathrm{~cm}$} & \multicolumn{4}{|c|}{$499 \mathrm{D}-1-1,33-35 \mathrm{~cm}$} & \multicolumn{4}{|c|}{$500-18-1,52-54 \mathrm{~cm}$} \\
\hline Analysis No. & 90 & 91 & 92 & 93 & 94 & 95 & 96 & 97 & 98 & 99 & 100 \\
\hline $\mathrm{SiO}_{2}$ & 50.64 & 53.53 & 51.42 & 51.53 & 50.93 & 50.81 & 50.83 & 45.04 & 44.87 & 45.39 & 46.43 \\
\hline $\mathrm{TiO}_{2}$ & 0.91 & 0.42 & 0.83 & 0.87 & 0.94 & 0.95 & 0.98 & 5.01 & 4.16 & 3.93 & 3.37 \\
\hline $\mathrm{Al}_{2} \mathrm{O}_{3}$ & 1.89 & 1.41 & 2.34 & 2.47 & 1.71 & 2.02 & 1.40 & 5.32 & 7.30 & 6.07 & 6.64 \\
\hline $\mathrm{Cr}_{2} \mathrm{O}_{3}$ & 0.00 & 0.12 & 0.00 & 0.87 & 0.94 & 0.12 & 0.00 & 0.00 & 0.09 & 0.16 & 0.13 \\
\hline $\mathrm{FeO}$ & 14.55 & 8.40 & 10.00 & 10.44 & 16.85 & 13.61 & 20.68 & 10.44 & 10.42 & 11.49 & 9.73 \\
\hline $\mathrm{MnO}$ & 0.35 & 0.32 & 0.18 & 0.27 & 0.43 & 0.42 & 0.40 & 0.15 & 0.21 & 0.30 & 0.20 \\
\hline $\mathrm{MgO}$ & 14,46 & 19.29 & 15.67 & 16.23 & 16.16 & 14.02 & 13.03 & 11.23 & 10.61 & 9.79 & 11.97 \\
\hline $\mathrm{CaO}$ & 16.68 & 17.26 & 19.17 & 17.50 & 12.14 & 16.94 & 13.15 & 20.48 & 21.50 & 21.25 & 21.00 \\
\hline $\mathrm{Na}_{2} \mathrm{O}$ & 0.33 & 0.21 & 0.28 & 0.24 & 0.16 & 0.35 & 0.24 & 0.98 & 0.57 & 0.69 & 0.50 \\
\hline $\mathrm{K}_{2} \mathrm{O}$ & 0.00 & 0.02 & 0.00 & 0.05 & 0.00 & 0.00 & 0.01 & 0.00 & 0.00 & 0.03 & 0.02 \\
\hline Total & 99.81 & 100.98 & 99.89 & 100.47 & 100.26 & 99.24 & 100.72 & 98.65 & 99.73 & 99.10 & 99.99 \\
\hline $\mathrm{Ca}$ & .44 & $t$ & 39.1 & .13 & 25.23 & 35.74 & 7.5 & 46. & 46.25 & 48.22 & 46.25 \\
\hline $\mathrm{Mg}$ & .54 & 52.71 & 44.56 & 46.60 & 6.72 & 41.14 & 7.98 & 35.22 & 36.66 & 30.90 & 36.67 \\
\hline $\mathrm{Fe}+\mathrm{Mn}$ & 24.02 & 13.38 & 16.26 & 17.27 & 28.05 & 23.12 & 34.48 & 18.63 & 27.08 & 20.88 & 17.08 \\
\hline Sample & \multicolumn{4}{|c|}{$500-19-1,24-28 \mathrm{~cm}$} & \multicolumn{7}{|c|}{$500 \mathrm{~B}-3-1,79-88 \mathrm{~cm}$} \\
\hline Analysis No. & 101 & 102 & 103 & 104 & 105 & 106 & 107 & 108 & 109 & 110 & 111 \\
\hline $\mathrm{SiO}_{2}$ & 46.66 & 44.53 & 44.54 & 43.39 & 50.79 & 51.16 & 51.00 & 51.52 & 51.42 & 51.48 & 50.61 \\
\hline $\mathrm{TiO}_{2}$ & 2.89 & 3.80 & & 4.88 & 1.00 & 0.83 & 0.77 & 0.73 & 0.79 & 0.85 & 0.89 \\
\hline $\mathrm{Al}_{2} \mathrm{O}_{3}$ & 6.79 & 6.56 & 7.00 & 6.69 & 4.47 & 2.92 & 4.22 & 4.30 & 3.26 & 2.81 & 2.33 \\
\hline $\mathrm{Cr}_{2} \mathrm{O}_{3}$ & 0.01 & 0.20 & 0.16 & 0.00 & 0.21 & 0.02 & 0.64 & 0.31 & 0.22 & 0.00 & 0.00 \\
\hline $\mathrm{FeO}$ & 9.75 & 12.10 & 12.12 & 15.70 & 7.95 & 10.31 & 6.06 & 6.06 & 9.09 & 10.25 & 15.66 \\
\hline $\mathrm{MnO}$ & 0.32 & & 0.31 & 0.44 & 0.21 & 0.14 & 0.08 & 0.19 & 0.23 & 0.16 & 0.47 \\
\hline $\mathrm{MgO}$ & 11.49 & 10.98 & 10.09 & 7.86 & 15.70 & 16.41 & 16.24 & 16.31 & 16.23 & 16.61 & 15.29 \\
\hline $\mathrm{CaO}$ & 21.28 & 20.37 & 21.36 & 21.03 & 19.52 & 17.50 & 19.49 & 20.09 & 18.21 & 16.21 & 14.64 \\
\hline $\mathrm{Na}_{2} \mathrm{O}$ & 0.53 & 0.66 & 0.53 & 0.59 & 0.27 & 0.31 & 0.25 & 0.20 & 0.25 & 0.25 & 0.24 \\
\hline $\mathrm{K}_{2} \mathrm{O}$ & 0.01 & 0.06 & 0.02 & 0.01 & 0.00 & 0.00 & 0.00 & 0.00 & 0.00 & 0.00 & 0.00 \\
\hline Total & 99.73 & 99.51 & 100.01 & 100.59 & 100.12 & 99.60 & 98.75 & 99.71 & 99.70 & 98.62 & 100.13 \\
\hline $\mathrm{Ca}$ & 47.16 & 4 & 4 & 4 & 40 & 36 & 41.57 & 42.15 & 37.89 & 34.16 & 30.18 \\
\hline $\mathrm{Mg}$ & 35.42 & 33.74 & 31.13 & 24.54 & 45.76 & 47.09 & 48.21 & 47.61 & 46.97 & 48.70 & 43.86 \\
\hline $\mathrm{Fe}+\mathrm{Mn}$ & 17.42 & 21.30 & 21.52 & 28.27 & 13.34 & 16.81 & 10.22 & 10.24 & 15.14 & 17.14 & 25.96 \\
\hline
\end{tabular}

${ }^{a}$ Cores of phenocrysts: $79,81,83,87,89,93,105,107$. Corresponding rims: $80,82,84,88,90,94,106,108$. Groundmass pyroxenes: $85,86,91,92,95$ to $104,109,110,111$.

regarding elements of the first transition series. All the concentrations were determined by X-ray fluorescence (XRF) up to $\mathrm{Nb}$, except Sc (determined by neutron activation analysis-NAA) and $\mathrm{Co}$ and $\mathrm{Ni}$ (for which both $\mathrm{XRF}$ and NAA data are available). From $\mathrm{Sb}$ to U, all concentrations were obtained by NAA. For XRF determinations, matrix and instrumental effects were calculated according to the procedures described by Bougault et al., (1977). For NAA, the use of epithermal neutrons strongly diminishes the interferences of ${ }^{46} \mathrm{Sc}$ and ${ }^{55} \mathrm{Fe}$. Irradiation is performed in Cd vials; measurements are made with a $\mathrm{Ge}-\mathrm{Li}$ detector from four days to one month after irradiation (Jaffrezic et al., 1977).

The three samples from Leg 66, Hole 487 are almost identical and are part of the same basaltic unit (Joron et al., 1981); the significant differences observed for alkali metals are discussed farther on. For Site 495, the trace element data clearly show two units; one is represented by two sections (495-46-1, 495-47-1) and the other by four samples in Core 48. The two samples of Hole 499C are of similar composition and the two samples of Hole 500 are almost identical. Only one sample is available from Hole 499D and one from Hole 500B.

\section{Alteration}

Oceanic tholeiites are characterized by low alkali-metal content. The variations of alkali metals in these rocks must be interpreted very carefully in terms of magma genesis. The levels of concentrations of these elements in fresh oceanic tholeiites are approximately as follows: $\mathrm{Cs} \simeq 0.02 \mathrm{ppm}, \mathrm{Rb} \simeq 1 \mathrm{ppm}, \mathrm{K}_{2} \mathrm{O} \simeq 0.1 \%$. Because of these low levels of concentrations, the content of these elements in oceanic basalts is very sensitive to weathering by seawater (Hart, 1969). The uptake of these elements is evident in the case of strong alteration (e.g., Leg 51, Sites 417, 418, at 110 m.y., Donnelly et al., 1979; Bougault et al., 1979; Joron et al., 1980); the Rb concentrations, for example, pass from about $1 \mathrm{ppm}$ for 
Table 10. Sites 499 and 500: feldspar analyses (in \%). ${ }^{\mathrm{a}}$

\begin{tabular}{|c|c|c|c|c|c|c|c|c|c|c|c|c|}
\hline \multirow{2}{*}{$\frac{\text { Sample }}{\text { Analysis No. }}$} & \multicolumn{6}{|c|}{$499 \mathrm{~B}-10-1,40-46 \mathrm{~cm}$} & \multicolumn{6}{|c|}{$499 \mathrm{C}-1-1,38-43 \mathrm{~cm}$} \\
\hline & 112 & 113 & 114 & 115 & 116 & 117 & 118 & 119 & 120 & 121 & 122 & 123 \\
\hline $\mathrm{SiO}_{2}$ & 50.49 & 53.00 & 51.70 & 57.55 & 53.54 & 52.90 & 48.67 & 52.76 & 51.05 & 51.23 & 52.44 & 53.57 \\
\hline $\mathrm{TiO}_{2}$ & 0.01 & 0.04 & 0.00 & 0.06 & 0.03 & 0.04 & 0.00 & 0.00 & 0.00 & 0.00 & 0.10 & 0.08 \\
\hline $\mathrm{Al}_{2} \mathrm{O}_{3}$ & 30.68 & 29.40 & 30.62 & 26.29 & 29.21 & 29.27 & 32.23 & 29.10 & 29.86 & 30.38 & 29.67 & 28.82 \\
\hline $\mathrm{Cr}_{2} \mathrm{O}_{3}$ & 0.00 & 0.08 & 0.00 & 0.00 & 0.08 & 0.00 & 0.00 & 0.00 & 0.00 & 0.00 & 0.00 & 0.00 \\
\hline $\mathrm{FeO}$ & 0.46 & 0.68 & 0.47 & 0.88 & 0.65 & 0.88 & 0.28 & 0.61 & 0.37 & 0.53 & 0.50 & 0.79 \\
\hline $\mathrm{MnO}$ & 0.07 & 0.00 & 0.00 & 0.00 & 0.00 & 0.00 & 0.00 & 0.00 & 0.00 & 0.00 & 0.00 & 0.00 \\
\hline $\mathrm{MgO}$ & 0.25 & 0.23 & 0.31 & 0.12 & 0.16 & 0.18 & 0.22 & 0.11 & 0.25 & 0.19 & 0.17 & 0.13 \\
\hline $\mathrm{CaO}$ & 14.81 & 12.79 & 14.24 & 9.15 & 12.38 & 12.60 & 15.87 & 12.15 & 13.38 & 13.60 & 12.38 & 11.44 \\
\hline $\mathrm{Na}_{2} \mathrm{O}$ & 3.20 & 4.30 & 3.50 & 6.40 & 4.77 & 4.41 & 2.39 & 4.36 & 3.72 & 3.59 & 4.29 & 4.69 \\
\hline $\mathrm{K}_{2} \mathrm{O}$ & 0.01 & 0.03 & 0.05 & 0.04 & 0.00 & 0.00 & 0.00 & 0.00 & 0.04 & 0.00 & 0.00 & 0.00 \\
\hline Total & 99.98 & 100.55 & 100.89 & 100.49 & 100.82 & 100.28 & 99.66 & 99.09 & 98.67 & 99.52 & 99.55 & 99.52 \\
\hline $\mathrm{Ca}$ & 71.83 & 62.08 & 69.05 & 44.02 & 58.93 & 61.22 & 78.58 & 60.63 & 66.35 & 67.68 & 61.47 & 57.43 \\
\hline$\{\mathrm{Na}$ & 28.12 & 37.73 & 30.67 & 55.78 & 41.07 & 38.78 & 21.42 & 39.37 & 33.43 & 32.32 & 38.53 & 42.57 \\
\hline K & 0.05 & 0.19 & 0.28 & 0.20 & 0.00 & 0.00 & 0.00 & 0.00 & 0.22 & 0.00 & 0.00 & 0.00 \\
\hline Sample & \multicolumn{9}{|c|}{$499 \mathrm{C}-1-1,38-43 \mathrm{~cm}$} & \multicolumn{3}{|c|}{$499 \mathrm{D}-1-1,33-35 \mathrm{~cm}$} \\
\hline Analysis No. & 124 & 125 & 126 & 127 & 128 & 129 & 130 & 131 & 132 & 133 & 134 & 135 \\
\hline $\mathrm{SiO}_{2}$ & 54.35 & 56.58 & 58.08 & 57.61 & 58.89 & 60.86 & 63.61 & 53.83 & 56.99 & 53.90 & 51.44 & 59.16 \\
\hline $\mathrm{TiO}_{2}$ & 0.07 & 0.11 & 0.08 & 0.11 & 0.02 & 0.07 & 0.01 & 0.09 & 0.06 & 0.06 & 0.04 & 0.06 \\
\hline $\mathrm{Al}_{2} \mathrm{O}_{3}$ & 28.20 & 26.82 & 26.07 & 26.04 & 24.84 & 24.19 & 23.31 & 28.58 & 26.59 & 28.50 & 30.22 & 25.65 \\
\hline $\mathrm{Cr}_{2} \mathrm{O}_{3}$ & 0.00 & 0.02 & 0.02 & 0.09 & 0.00 & 0.00 & 0.02 & 0.00 & 0.04 & 0.00 & 0.02 & 0.06 \\
\hline $\mathrm{FeO}$ & 0.60 & 0.83 & 0.73 & 0.71 & 0.66 & 0.63 & 0.25 & 0.72 & 0.74 & 0.61 & 0.66 & 0.61 \\
\hline $\mathrm{MnO}$ & 0.00 & 0.03 & 0.00 & 0.00 & 0.00 & 0.12 & 0.00 & 0.00 & 0.00 & 0.00 & 0.00 & 0.01 \\
\hline $\mathrm{MgO}$ & 0.11 & 0.07 & 0.06 & 0.04 & 0.09 & 0.00 & 0.00 & 0.31 & 0.07 & 0.14 & 0.22 & 0.00 \\
\hline $\mathrm{CaO}$ & 11.08 & 9.38 & 9.01 & 8.72 & 7.80 & 6.58 & 4.09 & 11.52 & 9.20 & 11.34 & 13.11 & 7.83 \\
\hline $\mathrm{Na}_{2} \mathrm{O}$ & 5.11 & 6.05 & 6.35 & 6.64 & 6.99 & 7.39 & 9.11 & 4.71 & 5.98 & 4.86 & 3.43 & 6.99 \\
\hline $\mathrm{K}_{2} \mathrm{O}$ & 0.00 & 0.07 & 0.01 & 0.08 & 0.01 & 0.00 & 0.04 & 0.00 & 0.02 & 0.00 & 0.00 & 0.02 \\
\hline Total & 99.52 & 99.96 & 100.41 & 100.04 & 99.30 & 99.84 & 100.44 & 99.76 & 99.69 & 99.41 & 99.14 & 100.39 \\
\hline $\int_{\mathrm{Ca}}$ & 54.52 & 45.95 & 43.92 & 41.87 & 38.13 & 32.96 & 19.84 & 57.49 & 45.89 & 56.30 & 67.88 & 38.21 \\
\hline$\{\mathrm{Na}$ & 45.48 & 53.65 & 56.05 & 57.69 & 61.83 & 67.04 & 79.92 & 42.51 & 53.98 & 43.69 & 32.12 & 61.65 \\
\hline$(\mathrm{K}$ & 0.00 & 0.40 & 0.03 & 0.44 & 0.04 & 0.00 & 0.24 & 0.00 & 0.13 & 0.01 & 0.00 & 0.14 \\
\hline Sample & \multicolumn{4}{|c|}{$500-18-1,52-54 \mathrm{~cm}$} & \multicolumn{4}{|c|}{$500-19-1,24-28 \mathrm{~cm}$} & \multicolumn{4}{|c|}{$500 \mathrm{~B}-3-1,79-88 \mathrm{~cm}$} \\
\hline Analysis No. & 136 & 137 & 138 & 139 & 140 & 141 & 142 & 143 & 144 & 145 & 146 & 147 \\
\hline $\mathrm{SiO}_{2}$ & 51.07 & 50.04 & 54.05 & 51.39 & 50.75 & 52.99 & 52.90 & 52.61 & 54.37 & 51.97 & 58.40 & 65.58 \\
\hline $\mathrm{TiO}_{2}$ & 0.00 & 0.09 & 0.03 & 0.02 & 0.03 & 0.08 & 0.13 & 0.09 & 0.12 & 0.00 & 0.04 & 0.00 \\
\hline $\mathrm{Al}_{2} \overline{\mathrm{O}}_{3}$ & 30.78 & 32.09 & 28.34 & 30.79 & 31.41 & 28.79 & 27.39 & 29.36 & 28.07 & 28.99 & 25.78 & 23.12 \\
\hline $\mathrm{Cr}_{2} \mathrm{O}_{3}$ & 0.00 & 0.01 & 0.04 & 0.03 & 0.00 & 0.00 & 0.04 & 0.00 & 0.07 & 0.00 & 0.00 & 0.00 \\
\hline $\mathrm{FeO}$ & 0.28 & 0.45 & 0.68 & 0.32 & 0.26 & 0.89 & 2.57 & 0.70 & 0.67 & 0.57 & 0.99 & 0.23 \\
\hline $\mathrm{MnO}$ & 0.00 & 0.00 & 0.00 & 0.00 & 0.00 & 0.00 & 0.00 & 0.00 & 0.00 & 0.05 & 0.00 & 0.00 \\
\hline $\mathrm{MgO}$ & 13.75 & 0.22 & 0.15 & 0.20 & 0.21 & 0.32 & 0.62 & 0.21 & 0.12 & 0.22 & 0.04 & 0.07 \\
\hline $\mathrm{CaO}$ & 13.75 & 14.70 & 11.29 & 13.56 & 14.92 & 12.46 & 11.11 & 12.81 & 11.19 & 12.73 & 8.65 & 3.41 \\
\hline $\mathrm{Na}_{2} \mathrm{O}$ & 3.42 & 3.00 & 5.03 & 3.69 & 3.17 & 4.44 & 4.19 & 4.32 & 4.86 & 3.91 & 6.47 & 8.99 \\
\hline $\mathrm{K}_{2} \mathrm{O}$ & 0.22 & 0.08 & 0.37 & 0.19 & 0.13 & 0.22 & 0.64 & 0.17 & 0.01 & 0.00 & 0.09 & 0.01 \\
\hline Total & 99.81 & 100.68 & 99.98 & 100.19 & 100.88 & 100.19 & 99.59 & 100.27 & 99.48 & 98.44 & 100.46 & 101.41 \\
\hline $\mathrm{Ca}$ & 68.06 & 72.67 & 54.21 & 66.26 & & 59.99 & 57.11 & 61.52 & 55.95 & 64.26 & 42.26 & 17.31 \\
\hline$\{\mathrm{Na}$ & 30.63 & 26.84 & 43.68 & 32.64 & $27.56^{\prime}$ & 38.73 & 38.99 & 37.50 & 44.01 & 35.74 & 57.20 & 82.65 \\
\hline I K & 1.31 & 0.49 & 2.11 & 1.10 & 0.73 & 1.28 & 3.90 & 0.98 & 0.04 & 0.00 & 0.54 & 0.04 \\
\hline
\end{tabular}

${ }^{a}$ Core-to-rim compositional variations of phenocrysts: 112-113, 114-115, 118-121, 122-125, 126-129, 136-138, $140-141$. Groundmass plagioclases: 116, 117, 130-132, 133-135, 139, 142-147.

Table 11. Sites 499 and 500: analyses of manganiferous ilmenite and pyrophanite, magnesiochromite, actinolite, and chlorite (in \%). ${ }^{\mathrm{a}}$

\begin{tabular}{|c|c|c|c|c|c|c|c|c|c|c|c|c|c|}
\hline \multirow{2}{*}{$\frac{\text { Sample }}{\text { Analysis No. }}$} & \multicolumn{3}{|c|}{ 499B-10-1, 40-46 cm } & \multicolumn{7}{|c|}{$499 \mathrm{C}-1-1,38-43 \mathrm{~cm}$} & \multirow{2}{*}{$\begin{array}{l}499 \mathrm{D}-1-1 \\
\frac{33-35 \mathrm{~cm}}{158}\end{array}$} & \multicolumn{2}{|c|}{$\begin{array}{l}500 \mathrm{~B}-3-1, \\
79-88 \mathrm{~cm}\end{array}$} \\
\hline & 148 & 149 & 150 & 151 & 152 & 153 & 154 & 155 & 156 & 157 & & 159 & 160 \\
\hline $\mathrm{SiO}_{2}$ & 0.09 & 52.46 & 52.48 & 0.24 & 0.26 & 1.76 & 1.12 & 51.84 & 30.00 & 29.45 & 28.11 & 1.92 & 30.77 \\
\hline $\mathrm{TiO}_{2}$ & 0.53 & 0.18 & 0.25 & 50.52 & 50.98 & 48.91 & 50.07 & 0.34 & 0.00 & 0.04 & 0.00 & 49.79 & 00.00 \\
\hline $\mathrm{Al}_{2} \mathrm{O}_{3}$ & 23.45 & 2.66 & 3.06 & 0.00 & 0.00 & 0.36 & 0.07 & 2.16 & 16.92 & 16.25 & 17.37 & 0.09 & 16.67 \\
\hline $\mathrm{Cr}_{2} \mathrm{O}_{3}$ & 37.62 & 0.01 & 0.04 & 0.08 & 0.02 & 0.00 & 0.02 & 0.00 & 0.00 & 0.00 & 0.00 & 0.00 & 0.06 \\
\hline $\mathrm{FeO}$ & 22.23 & 15.05 & 18.62 & 25.82 & 29.77 & 27.39 & 25.74 & 18.70 & 20.49 & 19.61 & 23.63 & 37.64 & 18.26 \\
\hline $\mathrm{MnO}$ & 0.17 & 0.44 & 0.29 & 23.48 & 18.57 & 19.61 & 21.11 & 0.32 & 0.20 & 0.24 & 0.27 & 7.39 & 0.32 \\
\hline Mgo & 13.03 & 14.42 & 14.33 & 0.03 & 0.06 & 0.00 & 0.00 & 12.33 & 20.15 & 19.19 & 18.34 & 0.12 & 21.31 \\
\hline $\mathrm{CaO}$ & 0.25 & 12.86 & 7.41 & 0.21 & 0.47 & 1.34 & 1.26 & 10.10 & 0.18 & 0.21 & 0.07 & 1.36 & 0.09 \\
\hline $\mathrm{Na}_{2} \mathrm{O}$ & 0.03 & 0.65 & 0.84 & 0.00 & 0.02 & 0.09 & 0.00 & 0.42 & 0.07 & 0.11 & 0.00 & 0.03 & 0.01 \\
\hline $\mathrm{K}_{2} \mathrm{O}$ & 0.00 & 0.05 & 0.03 & 0.00 & 0.02 & 0.00 & 0.00 & 0.01 & 0.00 & 0.07 & 0.04 & 0.00 & 0.12 \\
\hline Total & 97.40 & 98.78 & 97.35 & 100.38 & 100.17 & 99.06 & 98.27 & 97.22 & 88.01 & 85.17 & 87.83 & 98.34 & 87.61 \\
\hline FM & & 0.376 & 0.425 & & & & & 0.464 & 0.366 & 0.367 & 0.422 & & 0.329 \\
\hline
\end{tabular}

a Magnesiochromite: 148; manganiferous ilmenite and pyrophanite: 151 and 152 (crystal $100 \mu \mathrm{m}$ large), 153, 154,159 (groundmass); actinolite: 149,150 (in patches), 155 (fibrous): chlorite: $156,157,158,160$. 
Table 12. Trace element data, Holes 487 (Leg 66) and 495, 499C, 499D, 500, 500B (Leg 67).

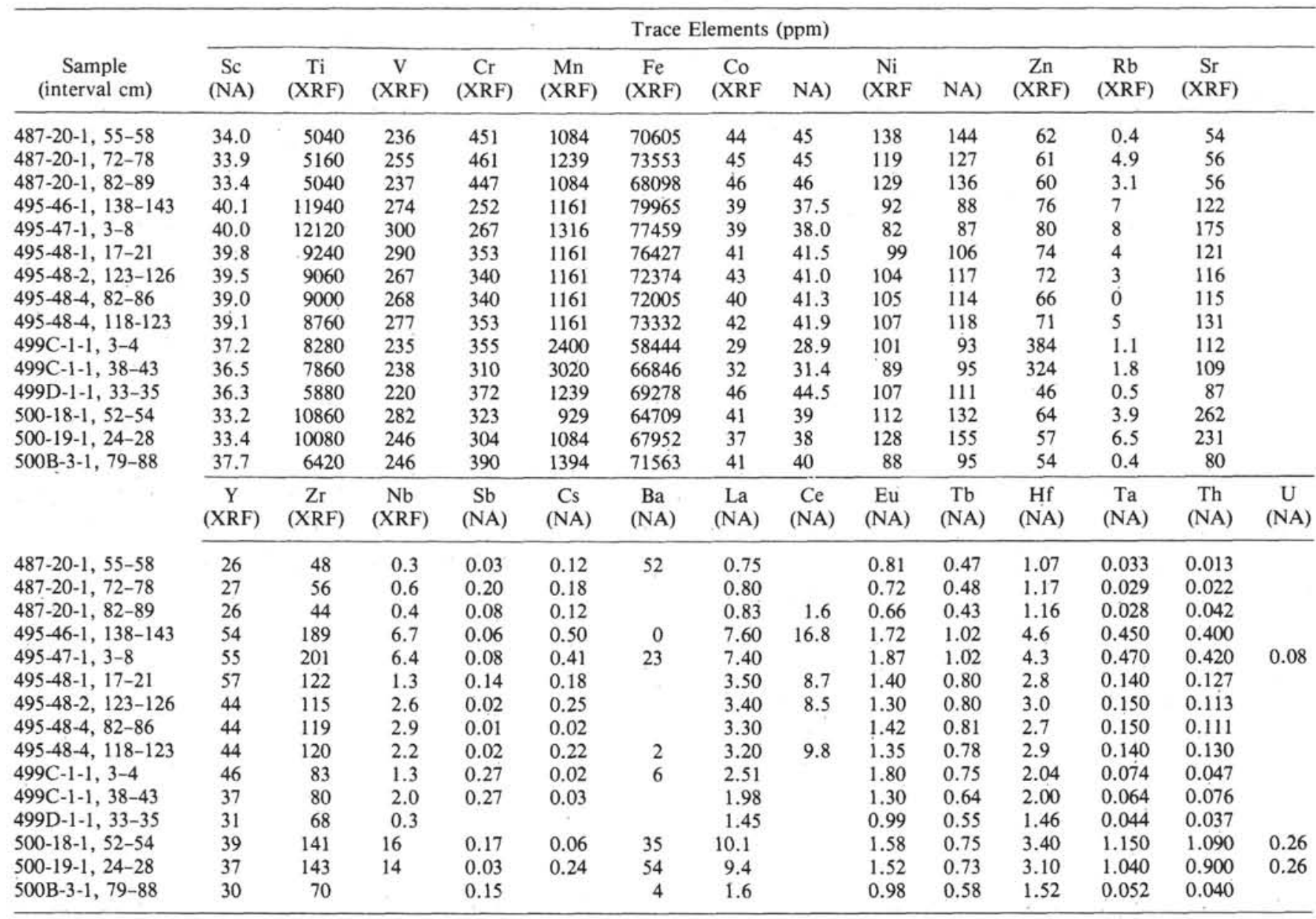

Note: $\mathrm{NA}=$ neutron activation analyses; $\mathrm{XRF}=\mathrm{X}$-ray fluorescence analyses.

fresh basalt to several tens of ppm for altered samples. Considering fresh oceanic basalts on the basis of thinsection observations and ignition loss at $110^{\circ} \mathrm{C}$ and $1050^{\circ} \mathrm{C}$ - which can be "negative" at $1050^{\circ} \mathrm{C}$ because of the uptake of oxygen by $\mathrm{Fe}^{++}$oxidation-the contamination by seawater can more than double the $\mathrm{Rb}$ content and increase the Cs content by a factor of 10 (Bougault et al., 1979).

A brief look at alkali-metals data from Legs 66 and $67\left(\mathrm{Rb}\right.$ and $\mathrm{Cs}$, Table $12 ; \mathrm{K}_{2} \mathrm{O}$, Tables $\left.1,2,3\right)$ shows a correlation among these alkali elements. This correlation is enhanced in a plot of Cs versus Rb (Fig. 4). In addition, a very good positive correlation is observed between the content of alkali elements and the ignition loss at $1050^{\circ} \mathrm{C}$ (see Table 12 for $\mathrm{Rb}$ and Cs and Tables 1,2 , and 3 for $\mathrm{K}_{2} \mathrm{O}$ and loss on ignition). This positive correlation (alkali content and ignition loss), which accounts for the intensity of alteration, is in agreement with the effect of seawater at low temperature mentioned earlier. Nevertheless, two exceptions to this alkali-ignition-loss relationship are observed: the two samples from Core 1 , Section 1 of Hole 499C.

Drastic chemical transformations are predicted from laboratory studies of seawater-basalt interactions at high

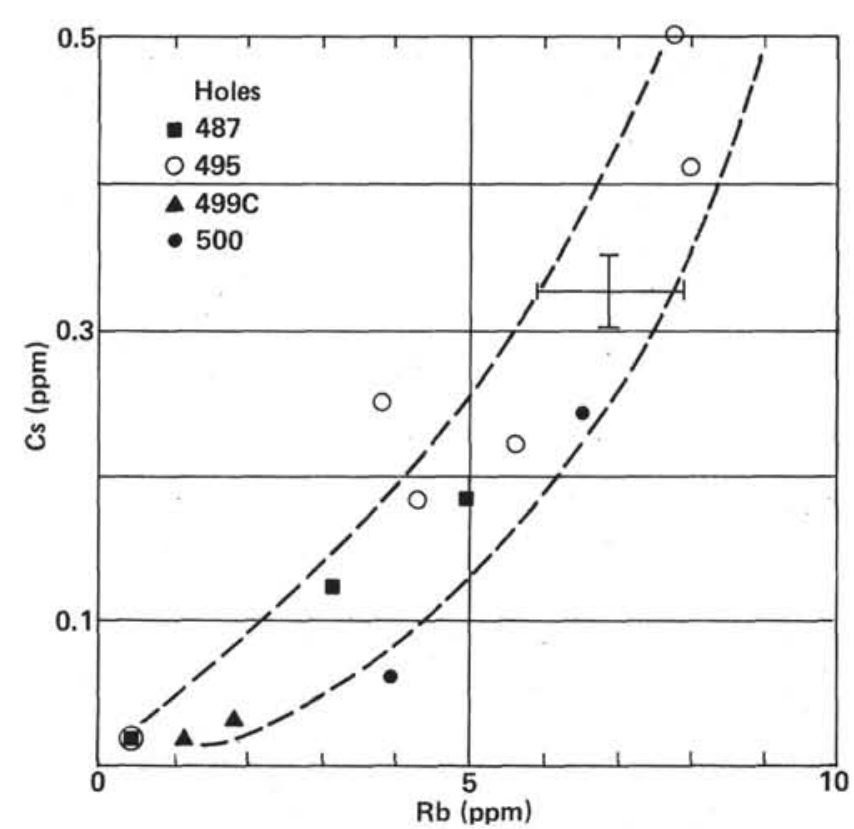

Figure 4. Cs (ppm) versus $\mathrm{Rb}(\mathrm{ppm})$ (the correlation between alkali metals for altered samples). 
temperatures and at seafloor pressures (Bischoff and Dickson, 1975; Hajash, 1975; Mottl and Holland, 1978). At mid-ocean ridges, temperatures of up to $380^{\circ} \mathrm{C}$ have been measured, sulfides are precipitated at the mouths of springs, and elements are removed from seawaters and from basalt. (Corliss et al., 1978; Corliss et al., 1979; Francheteau et al., 1979; Rise Project Group, 1980; and J. Honnorez et al., personal communication, 1981). Both experimental data and field observations indicate that alkali metals, Ca (Menzies and Seyfried, 1979; Edmond et al., 1979), and elements such as Mn, $\mathrm{Fe}, \mathrm{Zn}$, and $\mathrm{Cu}$ (Bischoff and Dickson, 1975; Seyfried and Bischoff, 1977; Hekinian et al., 1980; Boulègue et al., 1980) are leached from the rocks and transported to the seafloor. Alkali metals are then probably diluted in seawater; Mn starts to precipitate according to the rate of its oxidation from $\mathrm{Mn}^{++}$to $\mathrm{MnO}_{2}$; and most of the $\mathrm{Fe}, \mathrm{Cu}$, and $\mathrm{Zn}$ contents in hydrothermal fluids precipitate as sulphides at the mouth of hot hydrothermal springs on the seafloor or within the conduits to the seafloor, according to the temperature and the input of seawater. $\mathrm{Ca}$ has been found to precipitate as sulfate at the mouth of cooler springs. For the two samples from Core 1, Section 1 of Hole $499 \mathrm{C}$ the following characteristics are observed:

1) The highest loss of volatiles occurs at $110^{\circ} \mathrm{C}$ and the highest loss on ignition at $1050^{\circ} \mathrm{C}$; both results indicate that these samples underwent a strong action of fluids.

2) $\mathrm{Rb}$ and $\mathrm{Cs}$ are low and close to the limit of detection of the analytical techniques; $\mathrm{K}_{2} \mathrm{O}$ is in the range of unaltered low $\mathrm{K}$ tholeiites. These results preclude a lowtemperature seawater alteration leading to alkali enrichments, observed for other samples, and indicate hightemperature basalt-seawater interaction (Edmond et al., 1979; Menzies and Seyfried, 1979).

3) $\mathrm{Ca}$ is depleted $(\mathrm{CaO} \sim 7.2 \%)$ relative to classical $\mathrm{CaO}$ content $(12 \%)$ found, for instance, in Sample 499D$1-1,33-35 \mathrm{~cm}$ (which does not have the same characteristics of alteration); this fact also points to high-temperature seawater-basalt interaction (Edmond et al., 1979).

4) $\mathrm{Mn}$ and $\mathrm{Zn}$ concentrations are abnormally high, $\sim 2800 \mathrm{ppm}$ and $\sim 360 \mathrm{ppm}$, compared to classical 1400 ppm and $70 \mathrm{ppm}$ values in tholeiites. Considering the behavior of these elements mentioned earlier, these high concentrations can be interpreted as precipitations of these elements from hydrothermal fluids.

The interpretation that high-temperature seawaterbasalt interaction leads to low $\mathrm{K}, \mathrm{Rb}, \mathrm{Cs}$, and $\mathrm{Ca}$ values (the removal of alkali metals from basalt) and to $\mathrm{Mn}$ and $\mathrm{Zn}$ enrichment by early precipitation from fluids requires that there be no subsequent low-temperature alteration with time. This assumption is possible if we believe that fissures and conduits are quickly filled on the cessation of hydrothermal activity. In addition, we know that it is possible to preserve fresh basalts from seawater alteration for a million years (Donnelly et al., 1980).

\section{High Partition Coefficient and Hygromagmaphile Elements}

The concentrations of high partition coefficient elements $\mathrm{Cr}$ and $\mathrm{Ni}$ in tholeiites vary respectively from 600 ppm (Cr) and $250 \mathrm{ppm}(\mathrm{Ni})$ for primary liquids to 50 ppm ( $\mathrm{Cr}$ and $\mathrm{Ni}$ ) for differentiated liquids as crystallization proceeds. During this process Co content remains approximately constant, between 40 and 45 ppm (Bougault, 1977; Bougault et al., 1979). In this respect, it is clear that none of these basalts is "primary" and that all of them can be considered as liquids that have undergone fractional crystallization to different extents.

The Co content in these samples is in agreement with usual tholeiite concentrations except for the two samples from Hole 499C; 29 and 32 ppm are significantly lower than 40 to $45 \mathrm{ppm}$. We suggest that this observation could be connected with the high-temperature alteration mentioned earlier.

Extended Coryell-Masuda plots present the behavior of hygromagmaphile elements of the Transition Series $1,2,3$, and 4 , those elements whose ions show an electronic structure of rare gas (except V). Such a presentation incorporating non-rare-earth elements within rare earths has already been used to give a general picture of the relative fractionation of elements (e.g., White and Schilling, 1978; Kay et al., 1970; Tarney et al., 1979; Sun et al., 1979; Tarney et al., 1980; Morisson et al., 1980; Sun, 1980). The trends are generally interpreted in terms of primary genesis of rocks. Alkali metals are not used in the figures, because, as already shown, these elements are sensitive to alteration processes. Only the transition elements are used.

Among the data available in the literature, many results concern non-rare-earth elements on the one hand (e.g., Y, Zr, Nb; data are scarcer for the third Transition Series: sometimes $\mathrm{Hf}$ and $\mathrm{Ta}$ ) and rare-earths on the other. Very infrequently are all these elements discussed together for the same samples. Until recently, the correct place of non-rare-earths within the rare-earths field was uncertain in the extended Coryell-Masuda plot (which represents the comparative hygromagmaphileaffinity for the liquid phase-character of all of these elements). In addition, the concentration of non-rareearth elements in chondrites (for normalization) is not known with the required precision. For these reasons the diagrams proposed by Sun et al., (1979), Tarney et al., (1980) and Morisson et al., (1980) are not very precise as far as non-rare-earth elements are concerned.

The data accumulated since the FAMOUS operation and Leg 37, for the same powders, allowed us to obtain the following results. (1) The elements of the second and third Transition Series of Groups 3, 4, and 5 (Y/Tb; $\mathrm{Zr} / \mathrm{Hf} ; \mathrm{Nb} / \mathrm{Ta}$ ) do not fractionate one from the other; the ratios are close to the chondritic ratios (Y/Tb$\simeq 50 ; \mathrm{Zr} / \mathrm{Hf}=40$ [Fig. 5]; $\mathrm{Nb} / \mathrm{Ta}=16$ ). (2) Normalization values have been computed (Table 13) that are in the range of the proposed concentrations of chondrites in the literature. These values can be handled in the same way as "average rare earth" concentrations in chondrites. (3) The position of non-rare-earth elements within the rare-earths has been precisely determined by comparative geochemistry and also on more theoretical grounds, based on the cumulative effects of the incompatible character of these elements within a mineral structure and the complex formations in liquids (Bougault, 1980). (4) Using results (2) and (3), it is possible to 


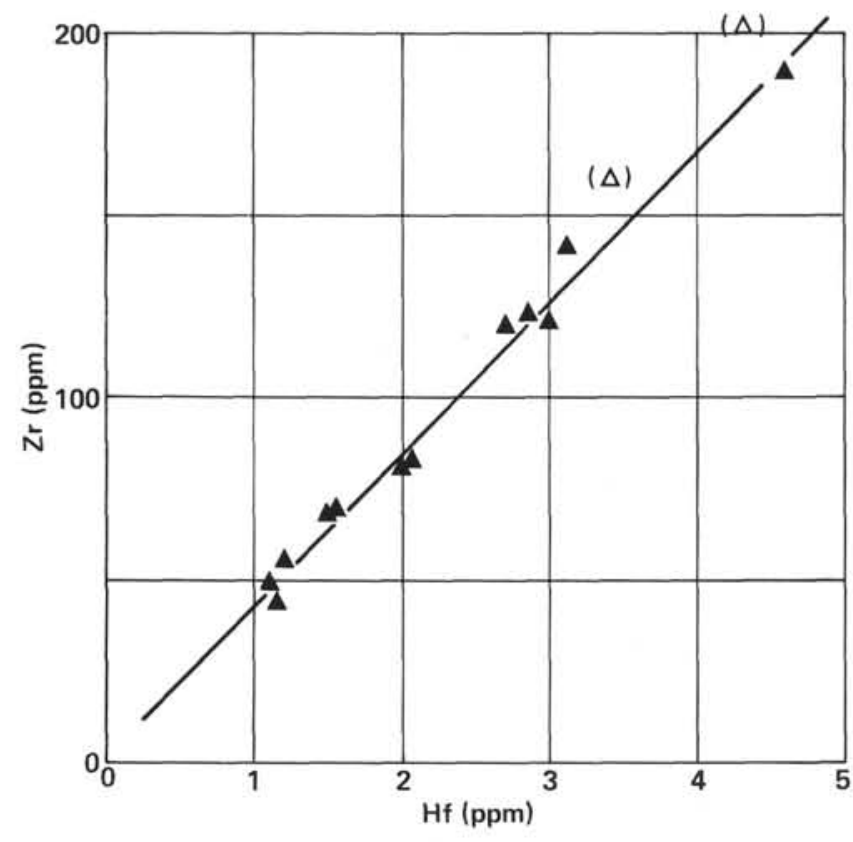

Figure 5. $\mathrm{Zr}$ (ppm) versus $\mathrm{Hf}(\mathrm{ppm})$ for Legs 66 and 67 samples. (The two open triangles-Samples 495-47-1, 3-8 cm and 500-18-1, 52$54 \mathrm{~cm}$-correspond very probably to an overestimation of $\mathrm{Zr}$, if compared with similar, if not identical, samples from each hole.)

Table 13. Normalization values.

\begin{tabular}{ccccccccccc}
\hline $\mathrm{Th}$ & $\mathrm{La}$ & $\mathrm{Ta}$ & $\mathrm{Nb}$ & $\mathrm{Zr}$ & $\mathrm{Hf}$ & $\mathrm{Ti}$ & $\mathrm{Eu}$ & $\mathrm{Tb}$ & $\mathrm{Y}$ & $\mathrm{V}$ \\
\hline 0.028 & 0.32 & 0.031 & 0.53 & 5.13 & 0.128 & 460 & 0.07 & 0.047 & 2.16 & 22 \\
\hline
\end{tabular}

obtain an extended Coryell-Masuda plot including nonrare-earth elements within the rare earths. The logarithm of normalized concentrations of non-rare-earth elements (ordinate) plot in this diagram with the same precision as the rare-earth values themselves. (5) Two values of the normalized $\mathrm{Ta} / \mathrm{La}$ ratio have been found: 1 and 0.5 , which are interpreted to be characteristic of mantle domain. This observation was evident in the papers of Sun et al., (1979) and Tarney et al., (1980) but not mentioned. In the Atlantic, this notion of mantle domain, initially termed "mantle blob" (Schilling, 1975), has been recently confirmed (Bougault and Treuil, 1980) using non-rare-earth elements and has in turn been correlated with isotopic results (Allègre et al., 1980; B. Dupré, personal communication, 1981).

In light of these investigations, what is the information that can be deduced from the present data regarding fundamental and comparative geochemistry, mantle heterogeneity?

A good example of the nonfractionation of the elements of each pair $\mathrm{Nb}-\mathrm{Ta}, \mathrm{Zr}-\mathrm{Hf}$, and $\mathrm{Y}-\mathrm{Tb}$ is given in Figure 5, where the $\mathrm{Zr} / \mathrm{Hf}$ ratio is very close to the value 40 found in basalts. The two open triangles correspond to Samples 495-47-1, 3-8 cm and 500-18-1, 53-54 cm and are very probably $\mathrm{Zr}$ overestimated by $10 \mathrm{ppm}$ when compared to similar, if not identical, Samples 495-46-1, $138-143 \mathrm{~cm}$ and $500-19-1,24-28 \mathrm{~cm}$, respectively. The
$\mathrm{Y} / \mathrm{Tb}$ correlation is also very good, but we think that $\mathrm{Y}$ has been overestimated by some ppm to account for the systematic upper position of this element relative to $\mathrm{Tb}$ in Figures 6 to 11. The $\mathrm{Nb} / \mathrm{Ta}$ ratio cannot be determined with precision due to low values observed in Holes 487, 495, 499C, 499D, and 500B. Nevertheless, the constancy of this ratio (16) can be estimated from the extended plots where $\mathrm{Nb}$ and $\mathrm{Ta}$ plot nearly at the same ordinate position. The precision of the extended diagram satisfies the result mentioned earlier-(4) which also involves results (2) and (3). The plots of the elements lying from $\mathrm{Zr}$ to $\mathrm{Y}$ in this diagram are demonstrative of that precision, as can be seen by comparing the ordinate positions of non-rare-earth elements to those of rare-earth elements.

Point (5) is very interesting: first of all, the distribution of the hygromagmaphile elements according to an extended Coryell-Masuda plot of Samples from Hole 500 (Fig. 11) is very different from the plots of other holes (Figs. 6-10). The rocks from Holes 487, 495, 499C, 499D, and 500B correspond to classical "depleted" tholeiites identical to those drilled during Leg 65 at $21^{\circ} \mathrm{N}$ on the East Pacific Rise (Cambon et al., in press), and during Leg 54 at $9^{\circ} \mathrm{N}$ and at the Galapagos spreading center (Joron et al., 1980). On the other hand, the two samples from Hole 500 show a significantly "light-rare-earth" enriched pattern similar to those obtained in the FAMOUS area (Langmuir et al., 1977). Correlatively, for Hole $500, \mathrm{Ta}, \mathrm{Nb}$, and La plot at the same ordinate position, which corresponds to the chondritic normalized $\mathrm{Ta} /$ La ratio $(=1$, like the FAMOUS area, Bougault and Treuil, 1980; and like the Emperor Seamounts, Cambon et al., 1980); $\mathrm{Nb}$ and $\mathrm{Ta}$ plot at a lower position than $\mathrm{La}$ for all other holes investigated in this study. This feature corresponds to an average normalized $\mathrm{Ta} / \mathrm{La}$ ratio of about 0.5 , as at $21^{\circ} \mathrm{N}$ and $9{ }^{\circ} \mathrm{N}$ on the East Pacific Rise, Galapagos Center, and the region of $20^{\circ} \mathrm{N}$ in the Atlantic (Joron et al., 1980; Bougault and Treuil, 1980). In light of the present interpretation of hygromagmaphile element behavior, we deduce that the Site 500 samples do not derive from the same "mantle domain" as the samples from other sites.

\section{CONCLUSIONS}

1. Typical oceanic crust. The occurrence of typical oceanic crust in the Guatemala Trench area is established. All the major mineralogical and geochemical features of oceanic tholeiites are preserved in the Trench itself (Hole 500) as well as its immediate vicinity (Site 495).

2. Heterogeneity. This crust is heterogeneous. Basalts from Hole 500 differ from the typically depleted oceanic tholeiites of Holes 495, 499, and 500B in their enrichment in light REE or equivalent elements in an extended Coryell-Masuda plot and in the "alkalic" tendency of their clinopyroxene mineralogy (salites). These differences mirror disparate chemical characteristics of verse mantle sources. We presently have no pertinent explanation for the coexistence in the same area of both REE-enriched and depleted basalts. So far, such an oc- 


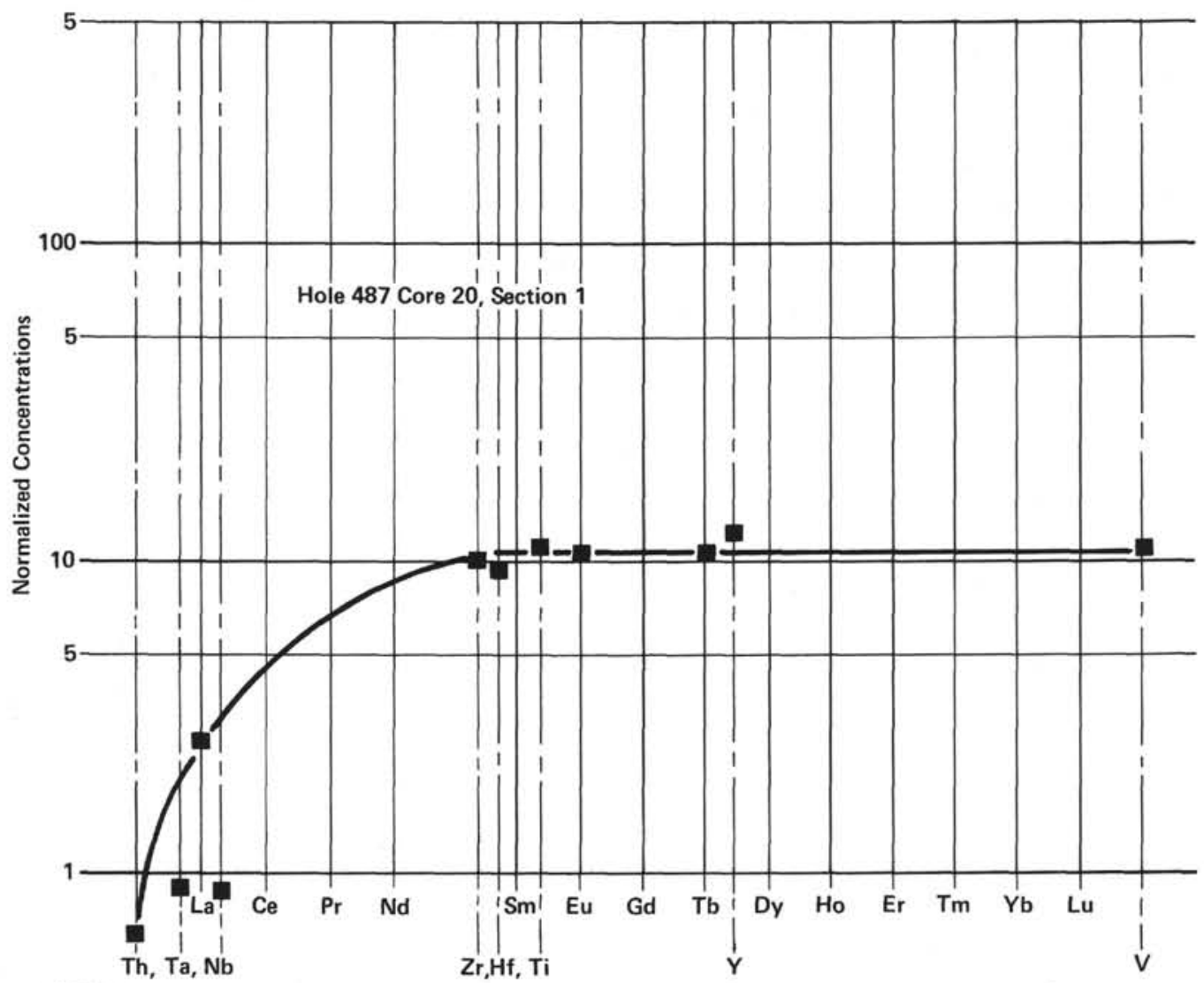

Figure 6. Extended Coryell-Masuda plot, Hole 487. (The sample is from Core 20, Section 1, as indicated).

currence has not been observed either in a given area (e.g., the FAMOUS area, sampling by submersible and dredging) or within a single drilled hole.

3. Hydrothermalism, metamorphism, and mineralization. With the exception of Hole 500, volcanic rocks from the Trench (Holes 499B, C, and D; 500D) and from the continental slope (Hole 494A) are characterized by their "spilitic" paragenesis involving mineral associations typical of greenschist facies metamorpism: actinolite + epidote + plagioclase + chlorite + quartz + calcite (Hole 494A); actinolite + plagioclase + chlorite + quartz + calcite (Holes 499B, C, and D; 500-D)-plagioclases ranging in composition from calcic "primary" plagioclase to nearly pure albite. Such metamorphic associations are frequently encountered in spilitic series of orogenic areas considered to be remnants of oceanic crust (e.g., Nicoya series; Azéma and Tournon, this volume) or of orogenic-type magmatism (e.g., Girard and Maury, 1980). They are also commonly found in samples dredged from ocean floors and ridges (e.g., Melson et al., 1968; Miyashiro et al., 1971; Jehl, 1975) and are considered the product of ocean-ridge metamorphism, the origin of which is attributed to hydrothermal (high-temperature) seawater-basalt interactions. The occurrence of actinolite-bearing assemblages in metabasites indicate temperatures higher than $300^{\circ}$ to $320^{\circ} \mathrm{C}$ (Spooner and Fyfe, 1973), and the thermal stability of plagioclase-chlorite-actinolite associations seems to be restricted to a range of $300^{\circ}$ to $475^{\circ} \mathrm{C}$ (Liou and Ernst,
1979). In the present case (Hole 499C), the distribution of alkali metals is satisfactorily explained by such a high-temperature seawater-basalt interaction.

Mineralogical evidence of postmagmatic mineralization, the origin of which can be attributed to hydrothermalism, has been found in samples from Holes 499C (pyrophanite-manganiferous ilmenite) and 500B (manganiferous ilmenite and pyrite). The former samples are characterized by positive anomalies of $\mathrm{Mn}$ and $\mathrm{Zn}$ contents, probably due to precipitations of these elements from hydrothermal fluids. The geological framework of that hydrothermalism is difficult to elucidate, owing to the reworked character of many samples (Holes 499C and $\mathrm{D} ; 500 \mathrm{~B})$. The only metamorphic sample considered to have been drilled from oceanic crust in situ is Sample 499B-10-1, 40-46 cm. The occurrence within one area of both fresh and altered oceanic crust has already been reported (Legs 51, 52, 53), and it is not surprising if we assume hydrothermal fluids to be circulating along normal faults. The similarity between the greenschist facies metamorphism developed in the oceanic crust and neighboring continental slope volcanics is striking.

4. Magmatic affinities of Hole $494 \mathrm{~A}$ lavas. These samples have undergone important chemical and mineralogical modifications of hydrothermal origin. Thus their primary character is not easy to identify, and the indications presently obtained are somewhat contradictory. Considering the available mineralogical data (clinopyroxene and plagioclase composition), an "active 


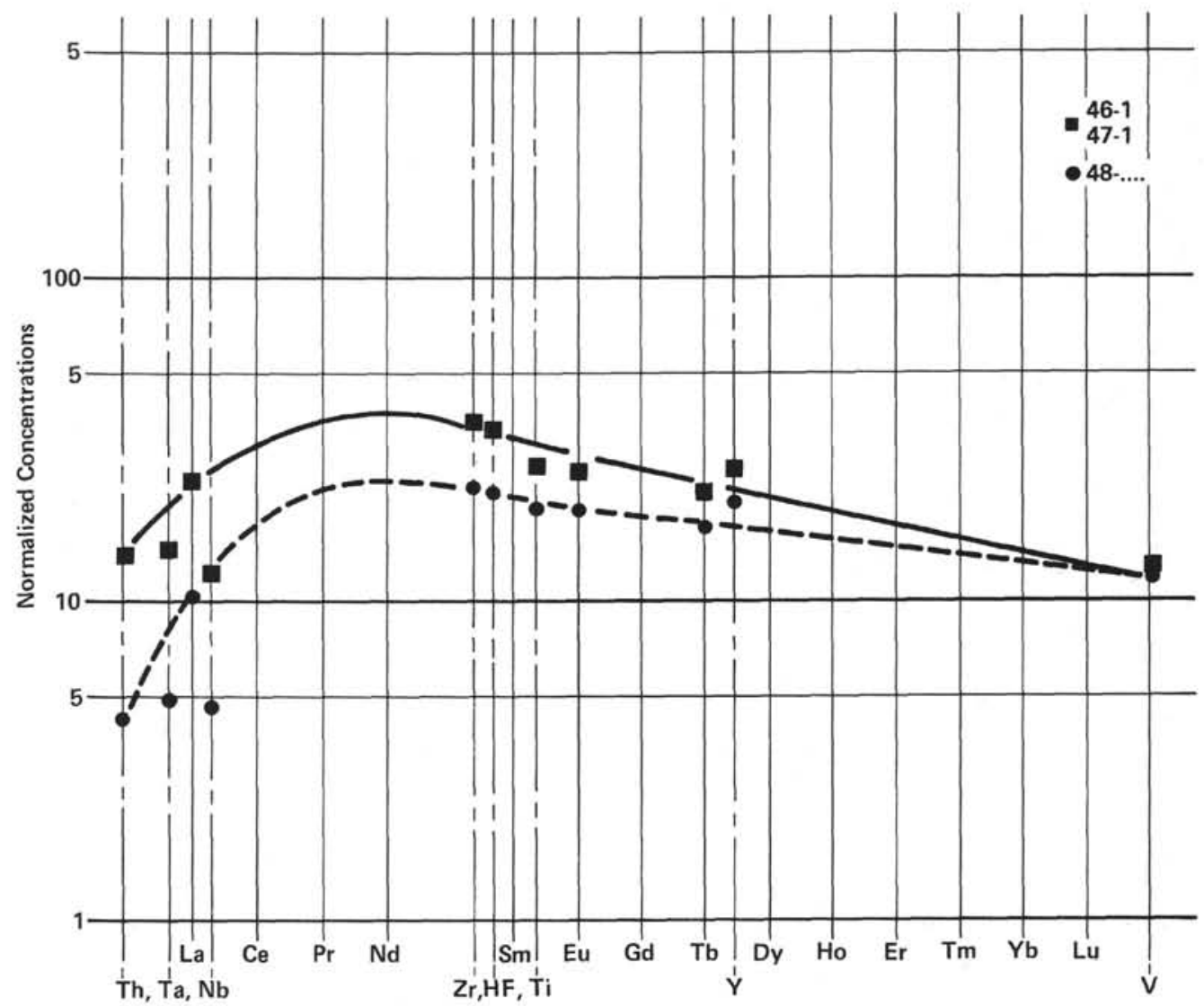

Figure 7. Extended Coryell-Masuda plot, Hole 495. (Cores [e.g., 46] and sections [e.g., 1] are indicated in the legend; for Core $48[\bullet]$, the plot corresponds to all analyzed samples of that core.)

margin" affinity is favored, which is also in agreement with the low concentrations of hygromagmaphile elements (Hf, Ti, Eu, Tb: Table 14 and Fig. 12). Nevertheless, the light rare-earth-element-depleted character (or hygromagmaphile equivalent elements) is unusual in orogenic lavas, even if observed for Tongan Island arc tholeiites (Ewart et al., 1973), but it is typical in oceanic tholeiites.

\section{REFERENCES}

Allègre, C. J., Brevart, O., Dupré, B., and Minster, J. F., 1980. Isotopic and chemical effects produced in a continuously differentiating convecting earth mantle. Philos. Trans. R. Soc. London, Ser. A, 297:447-477.

Aubouin, J., von Huene, R., and Leg 67 Scientific Team, 1979. Premiers résultats des forages profonds dans le Pacifique au niveau de la fosse du Guatemala (fosse d'Amérique Centrale) (Leg 67 du "Deep Sea Drilling Project": Mai-Juin 1979). C. R. Acad. Sci. Paris, Ser. D, 289:1215-1220.

Bischoff, J. L., and Dickson, F. W., 1975. Seawater-basalt interactions at $200^{\circ} \mathrm{C}$ and 500 bars: implications for the origin of seafloor heavy metal deposits and regulation of seawater chemistry. Earth Planet. Sci. Lett., 25:385-397.

Bougault, H., 1977. Evidence de la cristallisation fractionnee au niveau d'une ride medio-oceanique: $\mathrm{Co}, \mathrm{Ni}, \mathrm{Cr}, \mathrm{FAMOUS}$, Leg $37 \mathrm{du}$ D.S.D.P. Bull. Soc. Geol. Fr., (7) XIX:1207-1212.

1980. Contribution des elements de transition a la comprehension de la genese des basaltes oceaniques. Analyse des elements traces dans les roches par spectrometrie de fluorescence X [these]. Universite de Paris VII.

Bougault, H., Cambon, P., Corre, O., Joron, J. L., and Treuil, M., 1980. Evidence for variability of magmatic processes and upper mantle heterogeneity in the axial region of the Mid-Atlantic Ridge near $22^{\circ} \mathrm{N}$ and $36^{\circ} \mathrm{N}$. Tectonophysics, 55:11-34.

Bougault, H., Cambon, P., and Toulhost, H., 1977. X-ray spectrometric analysis of trace elements in rocks. Correction for instrumental interferences. $X$-Ray Spectrom., 6:66-72.

Bougault, H., Joron, J. L., and Treuil, M., 1979. Alteration, fractional crystallization, partial melting, mantle properties from trace elements in basalts recovered in the North Atlantic. In Talwani, M., Harrison, C. G., and Hayes, D. E. (Eds.), Deep Drilling Results in the Atlantic Ocean: Ocean Crust: Maurice Ewing Series (Vol. 2), (A.G.U.), 352-368.

Bougault, H., Maury, R. C., El Azzouzi, M., Joron, J. L., Cotten, J., and Treuil, M., 1982. Tholeiites, basaltic andesites and andesites from Leg 60 sites: Geochemistry, mineralogy and low partition coefficient elements. In Hussong, D., Uyeda, S., et al., Init. Repts. DSDP, 60: Washington (U.S. Govt. Printing Office), 657-678.

Bougault, H., and Treuil, M., 1980. Mid-Atlantic Ridge: zero-age geochemical variations between Azores and $22^{\circ} \mathrm{N}$. Nature, 286 (5770):209-212.

Boulègue, J., Michard, G., Bougault, H., and Charlou, J. L., 1980. Hydrothermal activity in the East Pacific Rise between $15^{\circ} \mathrm{N}$ and $7^{\circ} \mathrm{S}$. Eos, 61:992.

Brousse, R., Maury, R. C., in press. Titaniferous basanites and hawaiites from Mehetia, Society Islands, Central Pacific.

Cambon, P., Joron, J. L., Bougault, H., and Treuil, M., 1980. Leg 55 Emperor seamounts: trace elements in transitional tholeiites, alkali basalts, and hawaiites-mantle homogeneity or heterogeneity and magmatic processes. In Jackson, E. D., Koizumi, I., et al. Init. Repts. DSDP, 55: Washington (U.S. Govt. Printing Office), 585-597.

, in press. Leg 65: East Pacific Rise-typical oceanic crust depleted in hygromagmaphile elements. In Lewis, B.T. R., Robinson, P., et al., Init. Repts. DSDP, 65: Washington (U.S. Govt. Printing Office). 
Corliss, J. B., Dymond, J., Gordon, L. I., Edmond, J. M., Von Herzen, R. P., Ballard, R. D., Green, K., Williams, D., Bainbridge, A., Crane, K., and van Andel, Tj. H., 1979. Submarine thermal springs on the Galapagos Rift. Science, 203:1973-1983.

Corliss, J. B., Lyle, M., Dymond, J., and Crane, K., 1978. The chemistry of hydrothermal mounds near the Galapagos Rift. Earth Planet. Sci. Lett., 40:12-24.

Donnelly, T. W., Francheteau, J., Bryan, W., Robinson, P., Flower, M., and Salisbury, M., 1980. Init. Repts. DSDP, 51, 52, 53: Washington (U.S. Govt. Printing Office).

Donnelly, T. W., Thompson, G., and Robinson, P. T., 1979. Very low-temperature hydrothermal alteration of the oceanic crust and the problem of fluxes of potassium and magnesium. In Talwani, M., Harrison, C. G., and Hayle, D. E. (Eds.), Deep Drilling Results in the Atlantic Ocean: Ocean Crust: Maurice Ewing Series (Vol. 2), (A.G.U.), 369-382.

Edmond, J. M., Corliss, J. B., and Gordon, L. I., 1979. Ridge crest: hydrothermal metamorphism at the Galapagos spreading center and reverse weathering. In Talwani, M., Harrison, C. G., and Hayle, D. E. (Eds.), Deep Drilling Results in the Atlantic Ocean: Ocean Crust: Maurice Ewing Series (Vol. 2), (A.G.U.), 383-390.

Ewart, A., Bryan, W. B., and Gill, J. B., 1973. Mineralogy and geochemistry of the younger volcanic islands of Tonga, SW Pacific. J. Petrol., 14:429-465.

Francheteau, J., Needham, H. D., Choukroune, P., Juteau, T., Seguret, M., Ballard, R. D., Fox, P. J., Nordmark, W., Carranza, A., Cordoba, D., Guerrero, J., Rangin, C., Bougault, H., Cambon, P., and Hekinian, R., 1979. Massive deep-sea sulphide ore deposits discovered on the East Pacific Rise. Nature, 277(Wo 5697):523-528.

Galli-Olivier, C., 1979. Ophiolite and island-arc volcanism in Costa Rica. Geol. Soc. Am. Bull., 90:444-452.

Girard, D., and Maury, R. C., 1980. Affinite tholeiitique d'arc insulaire des spilites de l'ile de Tobago (Petites Antilles). C. R. Acad. Sci. Paris, Ser. D, 290:935-938.

Hajash, A., 1975. Hydrothermal processes along mid-ocean ridges. An experimental investigation. Contrib. Mineral. Petrol., 75:1-13.

Hart, S., 1969. K, Rb, Cs contents and $\mathrm{K} / \mathrm{Rb}, \mathrm{K} / \mathrm{Cs}$ ratios of fresh and altered submarine basalts. Earth Planet. Sci. Lett., 6: 295-303.

Hawkins, Sr., J. W., 1977. Petrologic and geochemical characteristics of marginal basin basalts. In Talwani M., and Pitman, III, W. C. (Eds.), Island Arcs Deep-sea Trenches, and Back-arc Basins: Maurice Ewing Series (Vol. 1), (A.G.U.), 355-366.

Hekinian, R., Fevrier, M., Bischoff, J. L., Picot, P., and Shanks, W. C., 1980. Sulphide deposits from the East Pacific Rise near $21^{\circ} \mathrm{N}$. Science, 207:1433-1444.

Jaffrezic, H., Joron, J. L., and Treuil, M., 1977. Trace elements determination in rock powder. A study of the precision for a given analytical procedure. Instrumental epithermal neutron activation. J. Radioanal. Chem., 39:185-188.

Jehl, V., 1975. Le metamorphisme et les fluides associes des roches oceaniques de l'Atlantique Nord [these]. Universite de Nancy.

Joron, J. L., Bollinger, C., Quisefit, J. P., Bougault, H., and Treuil, M., 1980. Trace elements in Cretaceous basalts at $25^{\circ} \mathrm{N}$ in the Atlantic Ocean: alteration, mantle compositions, and magmatic processes. In Robinson, P., Flower, M., and Salisbury, M., et al., Init. Repts. DSDP, 51, 52, 53, Pt. 2: Washington (U.S. Govt. Printing Office), 1087-1098.

Joron, J. L., Bougault, M., Maury, R. C., and Stephan, J. F., 1982. Basalt from the Cocos Plate (Site 487, Leg 66): petrology and geochemistry. In Watkins, J. S., Moore, J. C., et al., Init. Repts. DSDP, 66: Washington (U.S. Govt. Printing Office), 731-736.

Joron, J. L., Briqueu, L., Bougault, H., and Treuil, M., 1980. East Pacific Rise Galapagos spreading center and Siqueiros fracture zone, Deep Sea Drilling Project Leg 54: hygromagmaphile elements. A comparison with the North Atlantic. In Rosendahl, B. R., Hekinian, R., et al., Init. Repts. DSDP, 54: Washington (U.S. Govt. Printing Office), 725-735.

Kay, R., Hubbard, N. J., and Gast, P. W., 1970. Chemical characteristics and origin of oceanic ridge volcanic rocks. J. Geophys. Res., 73:1585-1613.

Konda, T., 1970. Endiopside in the calc-alkaline basalt in the Ryozen area. J. Geol. Soc. Jpn., 76:7-12.
Langmuir, C. H., Bender, J. F., Bence, A. E., Hanson, G. N., and Taylor, S. R., 1977. Petrogenesis of basalts from the FAMOUS area: Mid-Atlantic Ridge. Earth Planet. Sci. Lett., 36:133-156.

Leake, B. E., 1978. Nomenclature of amphiboles. Bull. Mineral., 101: 453-467.

Le Guen de Kerneizon, M., Mascle, A., Maury, R. C., and Westercamp, D., 1979. Les laves de la Desirade (Petites Antilles), temoins d'un magmatisme de marge active: arguments mineralogiques. Bull. Bur. Rech. Geol. Min. Sect. 4, 314:285-292.

Liou, J. G., and Ernst, W. G., 1979. Ocean ridge metamorphism of the East Taiwan ophiolite. Contrib. Mineral. Petrol., 68:335-348.

Marcelot, G., 1980. Contribution a l'etude du volcanisme des Nouvelles-Hebrides: petrographie, mineralogie et geochimie des laves d'Erromango [these]. Universite de Paris XI.

Maury, R. C., Brousse, R., Villemant, B., Joron, J. L., Jaffrezic, H., and Treuil, M., 1980. Cristallisation fractionnee d'un magma basaltique alcalin: la serie de la Chaine des Puys (Massif Central, France). 1. Petrologie Bull. Mineral., 103:250-266.

Melson, W. G., Thompson, G., and van Andel, Tj. H., 1968. Volcanism and metamorphism in the Mid-Atlantic Ridge, $22^{\circ} \mathrm{N}$ latitude. J. Geophys. Res., 73:5295-5941.

Menzies, M., and Seyfried, W. E., Sr., 1979. Basalt-seawater interaction, trace element and strontium isotopic variations in experimentally altered glassy basalt. Earth Planet. Sci. Lett., 44: 463-472.

Mevel, C., and Velde, D., 1976. Clinopyroxenes in Mesozoic pillow lavas from the French Alps: influence of cooling rate on compositional trends. Earth Planet. Sci. Lett., 32:158-164.

Miyashiro, A., Shido, F., and Ewing, M., 1971. Metamorphism in the Mid-Atlantic Ridge near $24^{\circ}$ and $30^{\circ} \mathrm{N}$. Philos. Trans. R. Soc. London Ser. A, 268:589-603.

Morisson, M. A., Thompson, R. N., Gibson, 1. L., and Marriner, G. F., 1980. Lateral chemical heterogeneity in the Palaeocene upper mantle beneath the Scottish Hebrides. Philos. Trans. R. Soc. London Ser. A., 297:229-244.

Mottl, M. J., and Holland, H. D., 1978. Chemical exchange during hydrothermal alteration of basalt by seawater. I. Experimental results for major and minor components of seawater. Geochim. Cosmochim. Acta, 42:1103-1115.

Rise Project Group, 1980. East Pacific Rise: hot springs and geophysical experiments. Science, 207:1421-1433.

Schilling, J. G., 1975. Rare earth variations across "normal segments" of the Reykjanes Ridge, $60^{\circ}-53^{\circ} \mathrm{N}$, Mid-Atlantic Ridge, $29^{\circ} \mathrm{S}$, and East Pacific Rise, $2^{\circ}-19^{\circ} \mathrm{S}$, and evidence on the composition of the underlying low-velocity layer. J. Geophys. Res., 80:1459-1473.

Schweitzer, E. L., Papike, J. J., and Bence, E. A., 1979. Statistical analysis of clinopyroxenes from deep-sea basalts. Am. Mineral. 64:501-513.

Seyfried, W., and Bischoff, J. L., 1977. Hydrothermal transport of heavy metals by seawater: the role of seawater/basalt ratio. Earth Planet. Sci. Lett., 34:71-77.

Sigurdsson, H., and Schilling, J. G., 1976. Spinels in Mid-Atlantic Ridge basalts: chemistry and occurrence. Earth Planet. Sci. Lett. 29:7-20.

Smith, D., and Lindsley, D. H., 1971. Stable and metastable augite crystallization trends in a single basalt flow. Am. Mineral., 56: 225-233.

Spooner, E. T. C., and Fyfe, W. S., 1973. Sub-sea-floor metamorphism, heat and mass transfer. Contrib. Mineral. Petrol., 42: 287-304.

Sun, S. S., 1980. Lead isotopic study of young volcanic rocks from mid-ocean ridges, ocean islands, and island arcs. Philos. Trans. $R$. Soc. London Ser. A, 297:409-445.

Sun, S. S., Nesbitt, R. W., and Sharaskin, A. Y., 1979. Geochemical characteristics of mid-ocean ridge basalts. Earth Planet. Sci. Lett., 44:119-138.

Tarney, J., Wood, D. A., Saunders, A. D., Cann, J. R., and Varet, J., 1980. Nature of mantle heterogeneity in the North Atlantic: evidence from deep sea drilling. Philos. Trans. R. Soc. London Ser. A, 297:179-202.

Tarney, J., Wood, D. A., Varet, J., Saunders, A. D., and Cann, J. R., 1979. Nature of mantle heterogeneity in the North Atlantic: evidence from Leg 49 basalts. In Talwani, M., Harrison, C. G., 
R. C. MAURY ET AL.

and Hayes, D. E. (Eds.), Deep Drilling Results in the Atlantic Ocean: Ocean Crust: Maurice Ewing Series (Vol. 2), (A.G.U.), 285-301.

Tracy, R. I., and Robinson, P., 1977. Zoned titanian augite in alkali olivine basalts from Tahiti and the nature of titanium substitutions in augite. Am. Mineral., 62:634-645.
White, W., and Schilling, J. G., 1978. The nature and origin of geochemical variation in Mid-Atlantic Ridge basalts from the central North Atlantic. Geochim. Cosmochim. Acta, 42:1501-1516.

Wood, D. A., Tarney, J., Varet, J., Saunders, A. A., Bougault, H., Joron, J. L., Treuil, M., and Cann, J., 1979. Geochemistry of basalts drilled in the North Atlantic by IPOD Leg 49: implications for mantle heterogeneity. Earth Planet. Sci. Lett., 42:77-97.

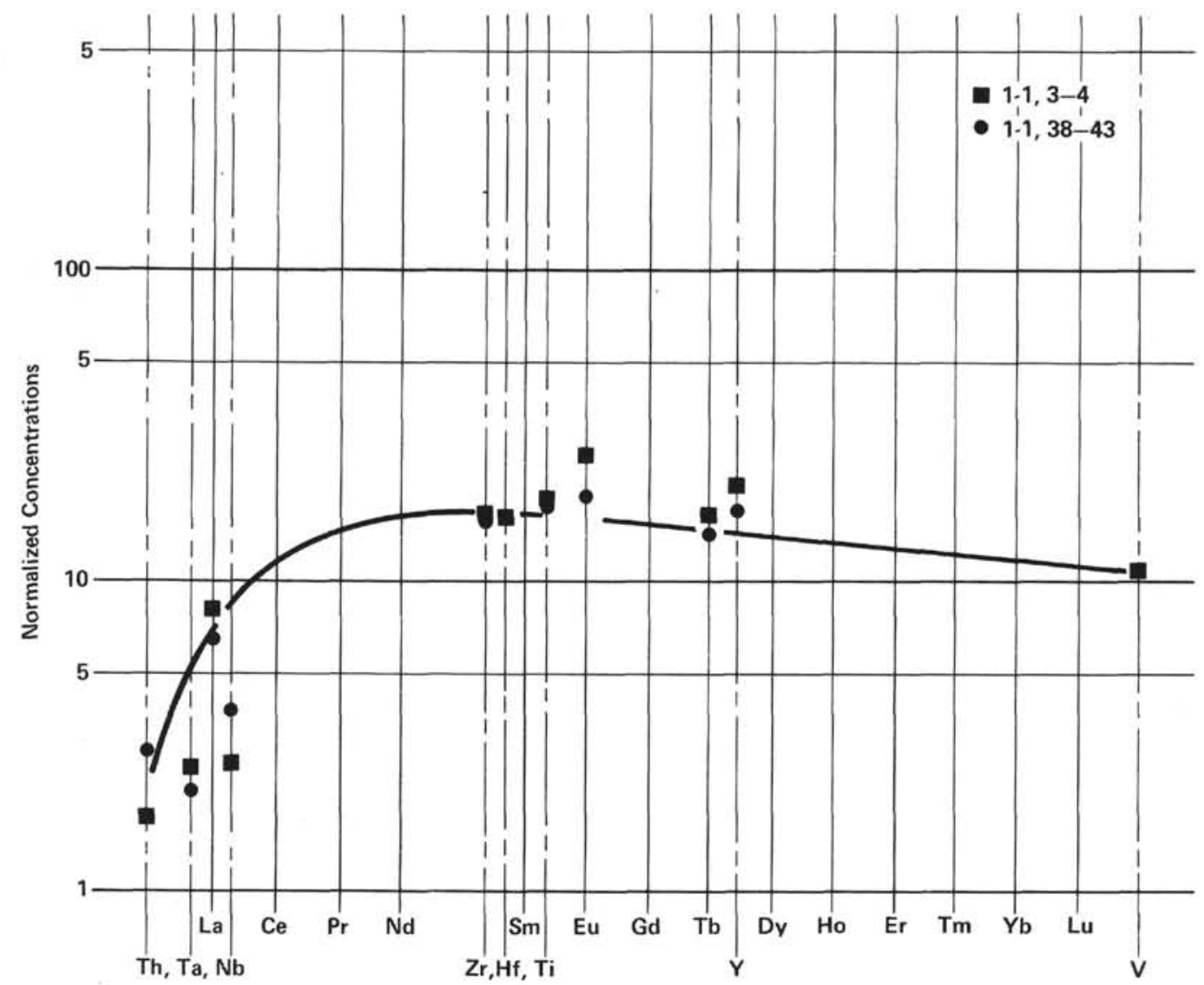

Figure 8. Extended Coryell-Masuda plot, Hole 499C. (Core-section, and interval in cm are indicated in the legend.) 


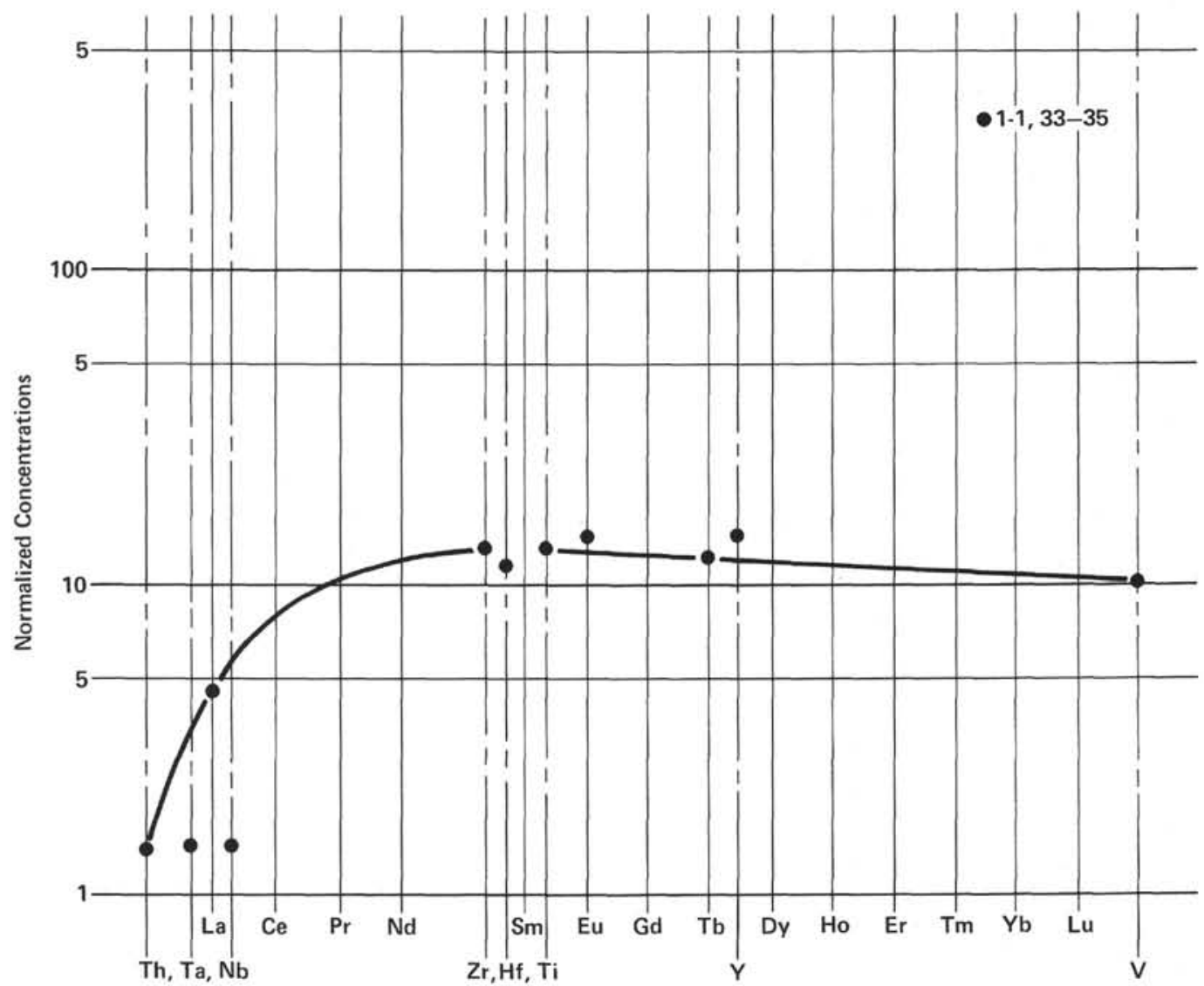

Figure 9. Extended Coryell-Masuda plot, Hole 499D. (Core-section, and interval in cm appear in legend.) 


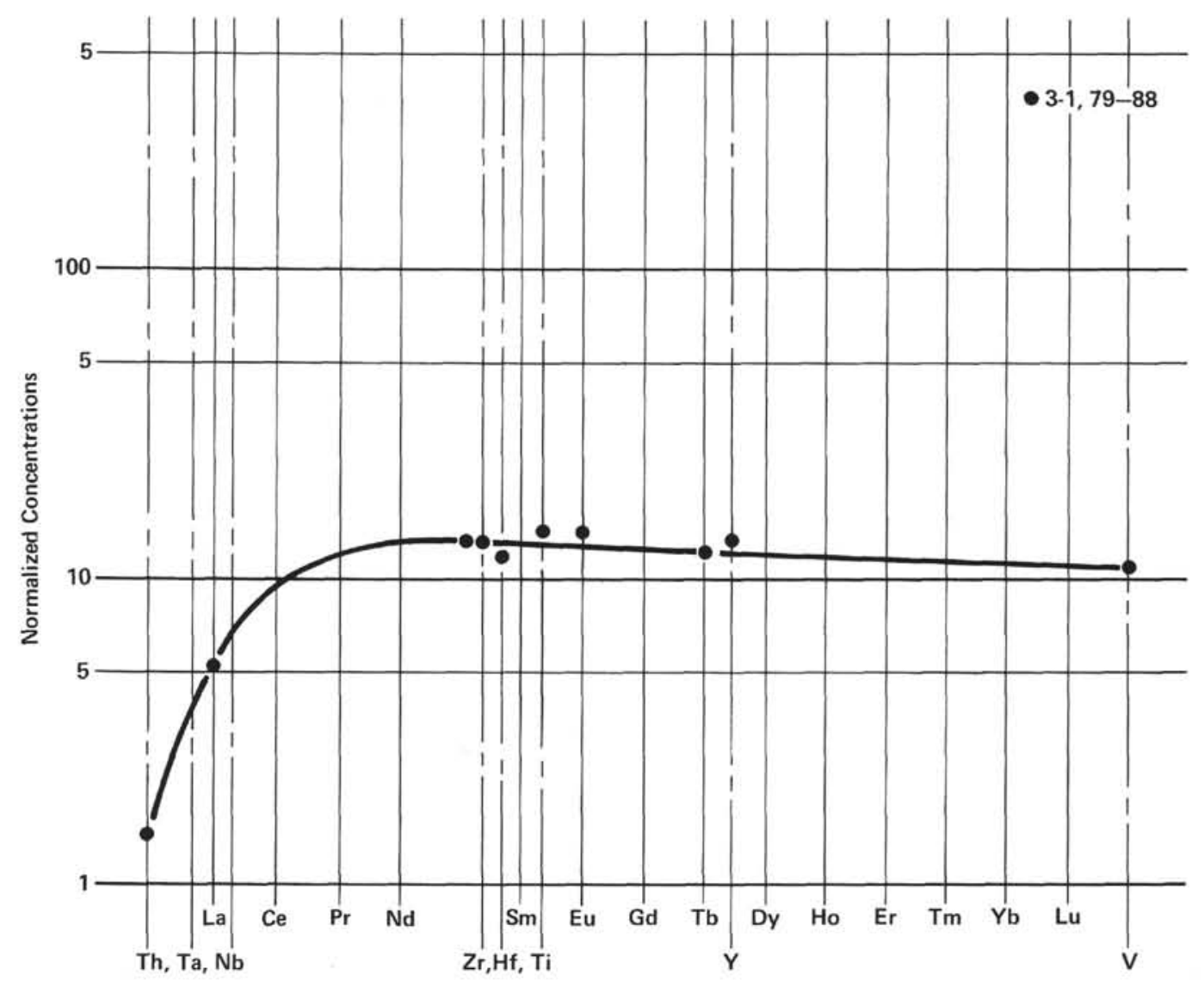

Figure 10. Extended Coryell-Masuda plot, Hole 500B. (Core-section, and interval in $\mathrm{cm}$ are noted.) 


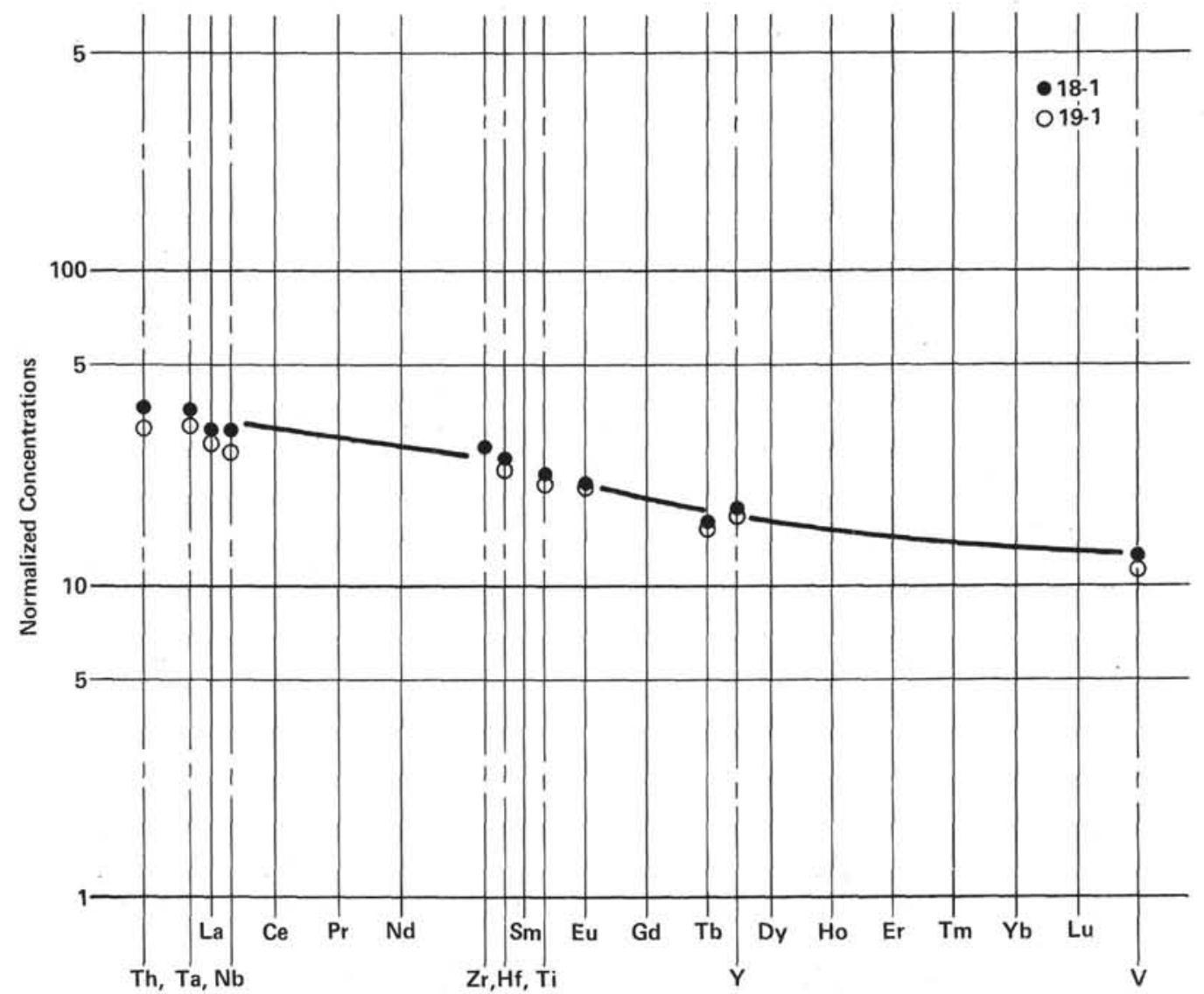

Figure 11. Extended Coryell-Masuda plot, Hole 500. (Cores and sections are indicated.)

Table 14. Trace elements analyses (ppm) of Hole 494A samples.

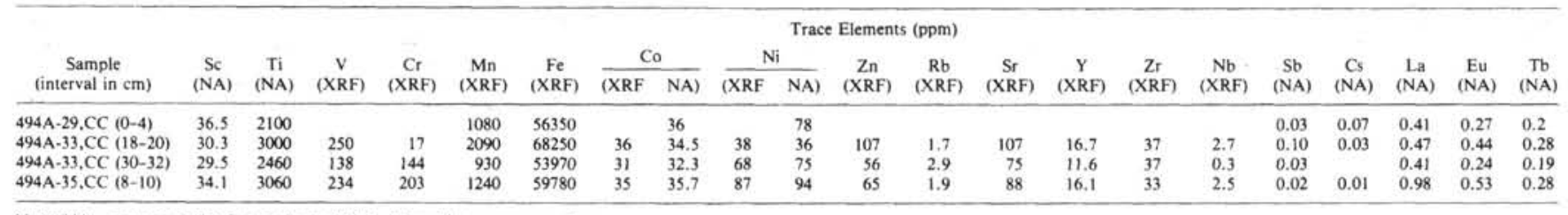

Note: $\mathrm{NA}=$ neutron activation analyses; $\mathrm{XRF}=\mathrm{X}$-ray fluorescence analyses. 
R. C. MAURY ET AL.

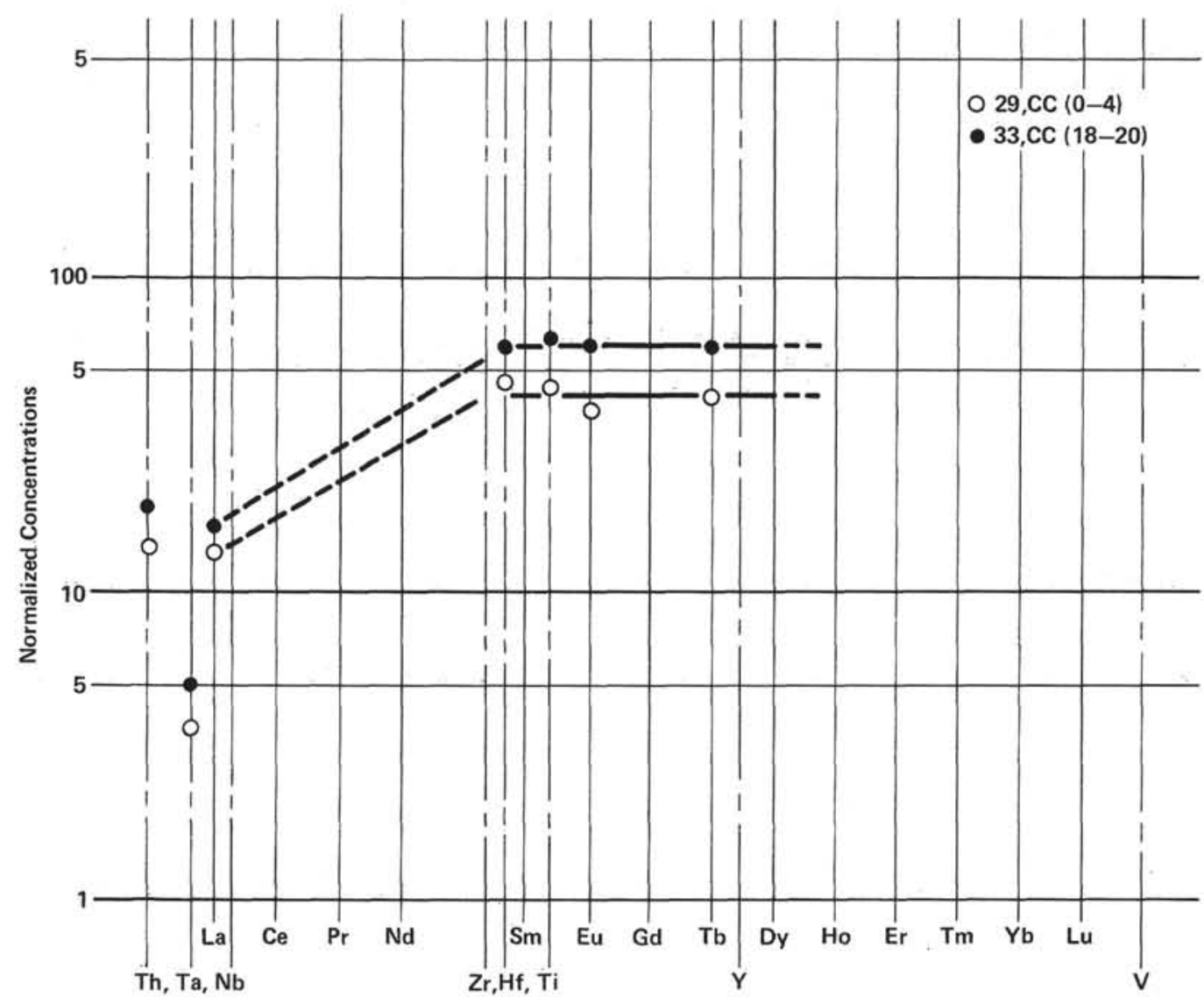

Figure 12. Extended Coryell-Masuda plot, Hole 494A. (Core-catcher sample and interval in $\mathrm{cm}$ are indicated.) 